\title{
EVOLUTION OF ANTIGEN BINDING RECEPTORS
}

\author{
Gary W. Litman \\ Department of Pediatrics, University of South Florida College of Medicine, All \\ Children's Hospital, St. Petersburg, Florida 33701; e-mail: litmang@ allkids.org \\ Michele K. Anderson and Jonathan P. Rast \\ Division of Biology, California Institute of Technology, Pasadena, CA 91125; \\ e-mail: manderso@cco.caltech.edu, jprast@cco.caltech.edu
}

KEY WORDS: vertebrate phylogeny, immunoglobulin, $\mathrm{T}$ cell antigen receptors, adaptive immunity, gene rearrangement

\begin{abstract}
This review addresses issues related to the evolution of the complex multigene families of antigen binding receptors that function in adaptive immunity. Advances in molecular genetic technology now permit the study of immunoglobulin (Ig) and T cell receptor (TCR) genes in many species that are not commonly studied yet represent critical branch points in vertebrate phylogeny. Both Ig and TCR genes have been defined in most of the major lineages of jawed vertebrates, including the cartilaginous fishes, which represent the most phylogenetically divergent jawed vertebrate group relative to the mammals. Ig genes in cartilaginous fish are encoded by multiple individual loci that each contain rearranging segmental elements and constant regions. In some loci, segmental elements are joined in the germline, i.e. they do not undergo genetic rearrangement. Other major differences in Ig gene organization and the mechanisms of somatic diversification have occurred throughout vertebrate evolution. However, relating these changes to adaptive immune function in lower vertebrates is challenging. TCR genes exhibit greater sequence diversity in individual segmental elements than is found in Ig genes but have undergone fewer changes in gene organization, isotype diversity, and mechanisms of diversification. As of yet, homologous forms of antigen binding receptors have not been identified in jawless vertebrates; however, acquisition of large amounts of structural data for the antigen binding receptors that are found in a variety of jawed vertebrates has defined shared characteristics that provide unique insight into the distant origins of the
\end{abstract}


rearranging gene systems and their relationships to both adaptive and innate recognition processes.

\section{INTRODUCTION}

The adaptive immune system is enormously complex. Its primary effector molecules are the antigen binding receptors [immunoglobulin (Ig) and $\mathrm{T}$ cell receptors (TCR)], which are members of the Ig gene superfamily that encompasses large numbers of related gene families serving diverse functions in separate cell lineages (1). The evolutionary acquisition of the complex set of diversification mechanisms found in the antigen binding receptors of present day mammals can be traced in part by comparisons to homologous genes of progressively more divergent vertebrate species. Superimposition of characters related to both sequence and genomic organization of Ig and TCR on the relatively well-established vertebrate phylogeny has proven critical in achieving our current understanding of their evolution. From both structural and functional perspectives, the evolution of Ig and TCR, which appear to be confined to the jawed vertebrates (Figure 1a), is unique and remarkably complex, as it is associated with particularly large families of diverse genes. Furthermore, the somatic diversification of the antigen binding regions of Ig and TCR, which occurs in all jawed vertebrates, is typically associated with a unique form of genetic rearrangement. In higher vertebrates, a second, unrelated form of somatic gene rearrangement takes place during Ig heavy-chain class switching and is associated with additional somatic diversification of germline genes. Antigen binding receptors also share signaling pathways with the nonrearranging mediators of innate immunity $(2,3)$. Thus, a broad interpretation of the evolution of antigen binding receptors needs to be framed within the boundaries of a highly diversified system in which effector molecules are selected on the basis of both templated germline diversity and untemplated somatic differences.

Although comparisons between Ig-type receptors in widely divergent groups have revealed extraordinary diversity in recombining systems, they simultaneously have defined common features that possibly represent constraining elements in the immune system. Broadscale comparisons can be used to generate hypotheses regarding the evolution of this diversity; however, only comparisons of more closely related species can be used to test their validity. As becomes apparent, the degree of plasticity in Ig gene organization and the mechanisms of diversification represent confounding aspects of a pure sequence comparison approach to the evolution of antigen binding receptors. This variation could not have been predicted (reconstructed in an evolutionary sense) by examining structure (and function) in the mammals alone. Although relatively 
few phylogenetic groups have been examined, within-group variation can be extreme. Every effort has been made in this review to emphasize common features in the Ig and TCR of diverse vertebrates and to relate differences in gene structure and organization that influence function.

\section{TWO MAJOR ANTIGEN BINDING RECEPTOR CLASSES ARE ENCODED BY REARRANGING GENES}

In addition to Ig and TCR, various members of the Ig superfamily have defined roles in the adaptive immune response, including major histocompatibility complex (MHC) I and MHC II, which recognize and bind portions of antigen and share $\mathrm{C} 1$ domain types with Ig and TCR (1). All four classes of genes are present in jawed vertebrates (Figures $1 a$ and 2). The structurally related but functionally distinct Igs and TCRs are considered to be the principal antigen binding receptors (4-6) and are the principal focus of this review. Ig and TCR are both structurally and organizationally related, function at the surface of cells, transduce signals along with coreceptors, and are the products of developmentally programmed rearrangement of segmental elements. Although somatic rearrangement and diversification are distinguishing features of Ig and TCR, even genetic rearrangement is not characteristic of all Ig loci $(7,8)$. In some species, specialized genetic processes exist for diversifying more limited numbers of recombining elements, whereas other species possess extremely large numbers of recombining elements. Rearranged Ig loci undergo extensive somatic hypermutation, whereas TCR genes tend to be mutated only in specialized cellular microenvironments $(9,10)$. The overall extent of mutation, of forces driving selection of mutations (i.e. antigen dependence versus independence), and of temporal dependence of the mutation process likewise exhibit considerable interspecies variation $(10,11)$. Considering the relatively few species that have been characterized, the number of different gene diversification themes that have been identified is extraordinary.

\section{IMMUNOGLOBULIN GENES IN CARTILAGINOUS FISH}

\section{Heavy-Chain Genes}

The living cartilaginous fish, comprised of the two major radiations, 1. sharks, skates, and rays and 2 . chimaeras and ratfish, are the most phylogenetically distant vertebrate group relative to mammals in which Ig genes have been identified (12-14) (Figures $1 a$ and $1 b$ ). The cartilaginous fish diverged from a common 

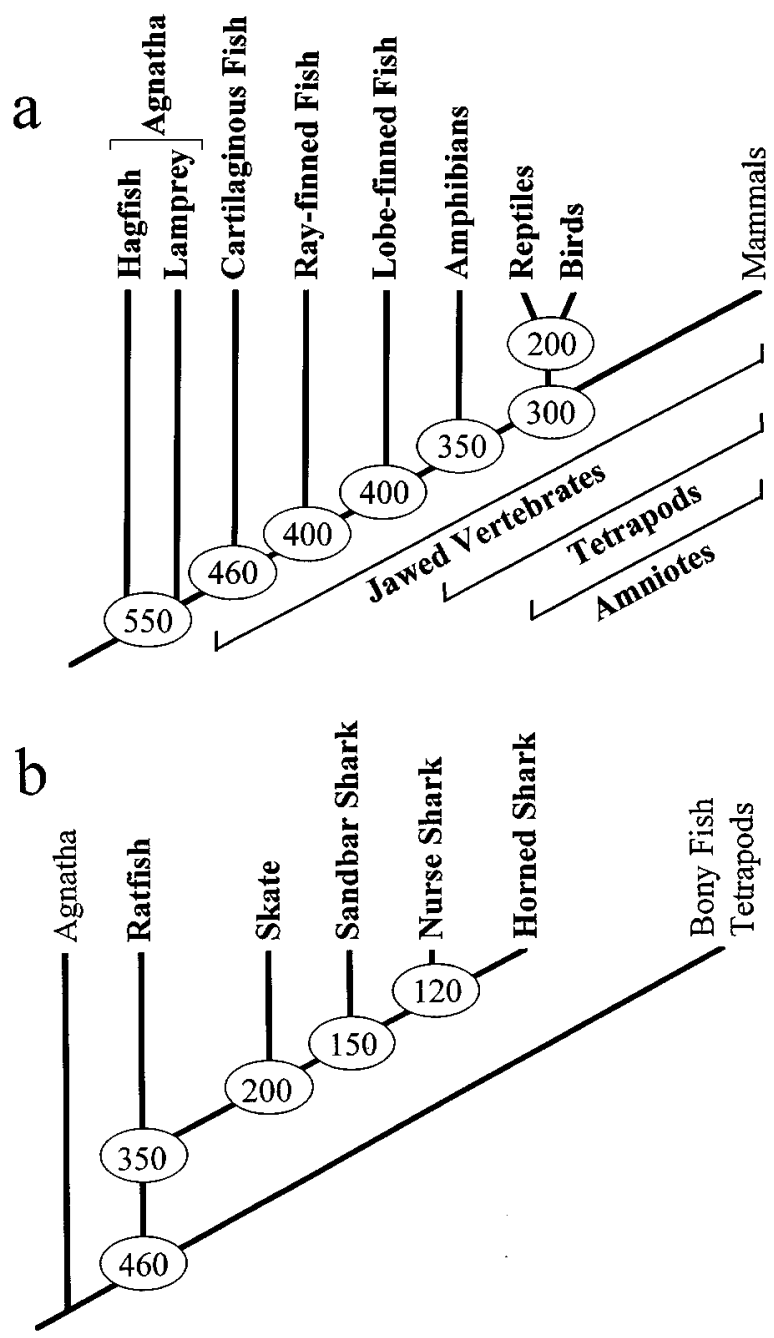

Figure 1 Phylogenetic relationships among the vertebrates. (a) Relationships among major vertebrate taxa; $(b)$ relationships among the cartilaginous fishes (class Chondrichthyes); $(c)$ relationships among the bony fishes: the ray-finned fishes (Actinopterygii) and the lobe-finned fishes (Sarcopterygii); and $(d)$ relationships among the tetrapods. (Ovals) Approximate divergence times, in millions of years ago, based on paleontologic evidence (15) or molecular comparisons (16); the accuracy of these estimates vary. 

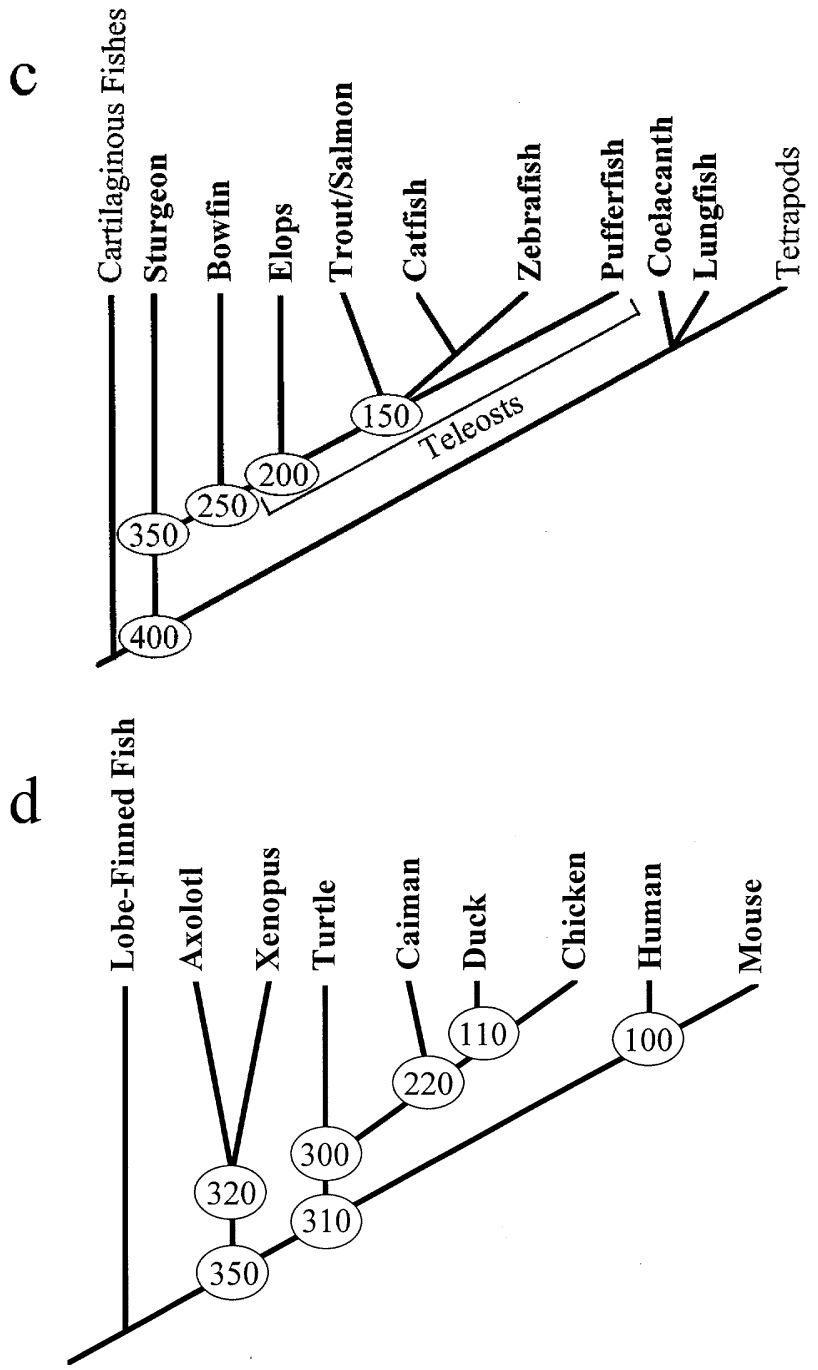

Figure 1 (Continued) 


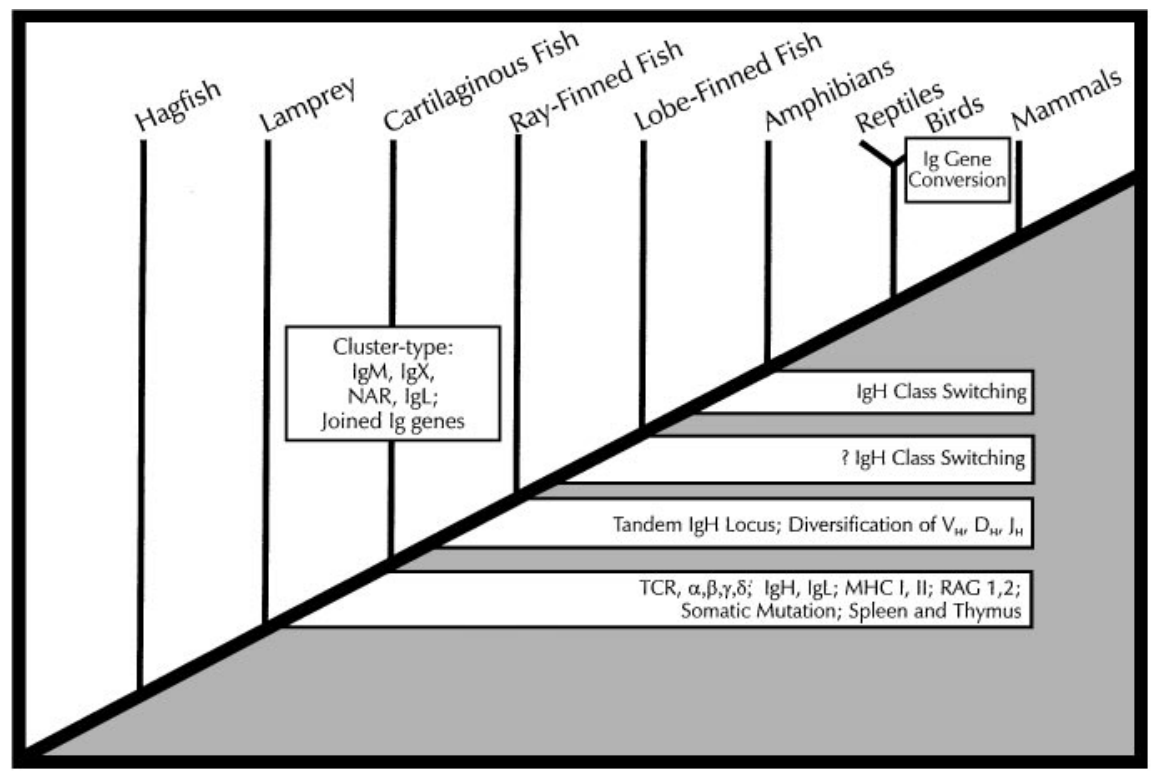

Figure 2 Major events in the evolution of rearranging antigen binding receptors superimposed on a phylogenetic tree of the major vertebrate groups. The placement of events relative to major vertebrate group divergence points is inferred from the data described in this review. Ig, immunoglobulin; IgH, Ig heavy chain; IgL, Ig light chain; NAR, novel antigen receptor; $\mathrm{D}_{\mathrm{H}}$, Ig heavy chain diversity region; $\mathrm{J}_{\mathrm{H}}$, Ig heavy chain joining region; $\mathrm{V}_{\mathrm{H}}$, Ig heavy chain variable region; $\mathrm{RAG}$, recombination activating gene; TCR, T cell receptor; MHC, major histocompatibility complex.

ancestor with the other living jawed vertebrates between 450 and 575 million years ago (MYA) $(15,16)$. In addition to IgM-type genes (hereafter referred to as IgM), other classes of Ig genes have been identified in these species. Certain features of IgM gene organization, structure, and function have been shown to be shared with higher vertebrate Ig, including the following: segmental rearrangement of V, D, and J elements (12); amino acid identity with the corresponding rearranging elements found in higher vertebrates $(7,17,18)$; separate Ig domains in single $\mathrm{C}$ region exons; differential processing of secretory and transmembrane (TM) forms $(14,19)$; and somatic mutation of rearranged genes (18) (see below). However, major differences are evident: (a) Multiplicity of loci, i.e. Ig heavy-chain genes in horned shark (Heterodontus francisci) are encoded in as many as 100 independently functional clusters in the genomic forms V-D ${ }_{1}-\mathrm{D}_{2}-\mathrm{J}-\mathrm{C}-\mathrm{TM}(20) ;(b)$ there is restricted intracluster rearrangement (18); (c) short (typically $<350 \mathrm{bp}$ ) intersegmental distances exist between rearranging elements $(7,13,21-23) ;(d)$ an additional D segment exists within clusters 
that increases the potential for junctional diversification $(7,18)$; $(e)$ there is germline joining of segmental elements in significant numbers of clusters $(7,8,13)$ (see below); and $(f)$ there is an absence of octamer binding sites and a presence of TCR $\beta$-type CRE elements (24). Furthermore, although the $\mathrm{V}_{\mathrm{H}}$ genes of tandemly organized loci, i.e. mammals, appear to evolve in a birthand-death turnover process (25), it is unclear whether cluster-type Ig genes are subject to the same diversifying process.

A single $\operatorname{IgM~} \mathrm{V}_{\mathrm{H}}$ family $\left(\mathrm{V}_{\mathrm{H}} 1\right)$ in the horned shark in which the members are $\sim 90 \%$ related at the peptide level accounts for all but one gene cluster $(7,18)$. The monotypic $\mathrm{V}_{\mathrm{H}} \mathrm{II}$ gene cluster, which is $\sim 60 \%$ identical to $\mathrm{V}_{\mathrm{H}} 1$ at the predicted peptide level, presumably diverged from a $\mathrm{V}_{\mathrm{H}} \mathrm{I}$-type gene by a process in which the intervening sequence (IVS) between $\mathrm{D}_{1}$ and $\mathrm{D}_{2}$ was excised and recombined in an inverted orientation, equivalent to a hybrid signal join. This results in a different utilization pattern for $\mathrm{D}_{1}$ and $\mathrm{D}_{2}$, and possible relief from any gene correction processes, thus allowing greater divergence. Analyses of the rearrangements of specific Ig gene clusters in horned shark have revealed typical patterns of junctional diversity and ruled out intercluster recombination of segmental elements. Junctional diversity presumably preceded combinatorial diversity in the evolution of mechanisms that diversify Ig genes (18).

The phenomenon of germline joining is unique to the cartilaginous fish. Germline-joined horned shark IgM heavy-chain genes (VD-J-C; VDJ-C), which comprise $50 \%$ of the clusters analyzed, resemble their unjoined counterparts in terms of overall exon organization and sequence relatedness $(7,18)$. Both VD-J-C- and VD-DJ-C-joined germline genes also are found in the IgM genes in little skate (Raja erinacea), which similarly possess nonjoined forms (13). Various lines of evidence indicate that these genes are derived from typical unrearranged ancestral genes $(7,8,26)$.

IgM gene clusters also have been identified in a separate lineage of cartilaginous fish represented by the ratfish (14). These are found in unjoined and joined forms and are related to the shark and skate IgMs. A variant IgM-type cluster recovered from a ratfish cosmid library possesses a first constant region exon that lacks significant sequence identity with $\mathrm{C}_{\mathrm{H}} 1$ from the $\mathrm{IgM}$ genes found in this species. Duplication of a $\mathrm{C}_{\mathrm{H}} 2$ exon and loss of a typical $\mathrm{C}_{\mathrm{H}} 1$ exon accounts for this difference (14). The IgM variant lacks the cysteine residue in $\mathrm{C}_{\mathrm{H}} 1$ that participates in interchain disulfide bonding with light chain, which suggests that it could function either as a single-folded chain or as a homodimer. This presumably derived character also has been reported in the nurse shark (Ginglymostoma cirratum) novel antigen receptor (NAR) $(22,27)$ and in camel $\operatorname{IgG}(28,29)$. A completely germline-joined IgM, which has been shown to be expressed in both secretory and TM forms, and an extensive family of pseudogenes, comprising $\sim 90 \%$ of all $\mathrm{V}_{\mathrm{H}}$ hybridizing segments, also are present in this species (14). 
$\operatorname{IgX}$, a second distinct class of cluster-type Ig heavy-chain gene, has been described from skates. $\mathrm{V}_{\mathrm{X}}$ is $\sim 60 \%$ identical at the nucleotide and amino acid levels to the $\mathrm{V}_{\mathrm{H}}$ of the cartilaginous fish IgM genes (30). IgX clusters contain two $\mathrm{D}$ and one $\mathrm{J}$ segment as well as two $\mathrm{C}_{\mathrm{X}}$ exons followed by a single cysteine-rich exon lacking a TM character (and by inference designated secretory) $(21,30)$. Multiple $\operatorname{IgX}$ (as well as IgM) clusters are present in skate (30). In situ hybridization studies with interphase nuclei demonstrate that both IgM and IgX clusters are found on multiple chromosomes and do not appear to be linked (21). The overall regulation, including possible allelic exclusion, of multiple cluster-type Ig loci, is not understood $(24,26)$; however, other multigene families encoding diverse specificities are also organized in multiple potentially independently functional loci (31). The complete genomic nucleotide sequence of an $\operatorname{IgX}$ locus up to the secretory exon has been reported (21). Although the structures of short regulatory motifs in the J-C IVS of both shark IgM and skate $\operatorname{IgX}$ are related closely to those important in the transcriptional regulation of mammalian Ig expression, their relative positions are not conserved (32). The functional significance of these motifs is not yet established (G Warr, D Ross, M Anderson, unpublished observations).

Longer IgX-related transcripts have been identified (30) and shown to consist of $\mathrm{V}_{\mathrm{X}}, \mathrm{C}_{\mathrm{X}} 1$, and $\mathrm{C}_{\mathrm{X}} 2$ as well as four additional Ig domains (21). $\operatorname{IgW}$ described in sandbar shark (Carcharhinus plumbeus) (33) and NARC (new antigen receptor from cartilaginous fish) described in nurse shark (34) consist of IgX-like $\mathrm{V}, \mathrm{C}_{1}$, and $\mathrm{C}_{2}$ regions as well as four additional $\mathrm{C}$ terminal regions $\left(\mathrm{C}_{3}-\mathrm{C}_{6}\right)$ (34), which are homologous to the last four exons of the long $\mathrm{IgX}$ transcript and exhibit significant identity with the corresponding regions of the nurse shark NAR (22) (see below). The relationship of IgX to IgW, NARC, and NAR in these three phylogenetically disparate species was examined further by characterizing both short and long forms of $\mathrm{IgX}$ in the skate; the short form has not been identified in any shark species at the molecular genetic level. The coding regions of the long and short forms of IgX share 90\% nucleotide identity, with differences concentrated in complementarity determining regions (CDRs) (23). Differential processing of the same locus most likely accounts for the extraordinary identities, which extend to include IVSs between $D_{X}$ elements (23).

NAR, a third class of Ig in cartilaginous fish, was identified in the nurse shark using polymerase chain reaction (PCR) that targeted shared sequence motifs in $\mathrm{C}_{1}$-type Ig domains (22). NAR possesses an unusual $\mathrm{V}$ region, which is not related closely to those of any particular Ig or TCR $\mathrm{V}$ regions, a truncated $\mathrm{C}_{1}$ domain, and four C-terminal Ig domains. Furthermore, NAR V regions, unlike those of conventional Ig and TCR, do not form dimers but presumably function as independent domains $(22,27)$. NAR possesses the same cluster-type 
genomic organization as $\operatorname{IgM}$ and $\operatorname{IgX}$ but each cluster contains three versus two D elements. Only four NAR loci have been identified in nurse shark, of which two are expressed and two presumably are pseudogenes. Two of the three $\mathrm{D}$ genes are germline-joined in one of the pseudogenes. Two $\mathrm{V}$ types are defined on the basis of differences in noncanonical cysteine residues that may stabilize the functional V monomer against variation (35). Cysteine residues in CDR3 are encoded typically by preferred reading frames of rearranged D segments (27). NAR has been identified in another species of shark and in sting ray (M Flajnik, personal communication). NAR undergoes extensive hypermutation (see below).

Several, but not all, of these features of NAR, i.e. its function as a single chain and the intermediate TCR-Ig V-like sequences are potential properties of a primordial antigen binding receptor $(22,27)$; however, the three D segments and extensive hypermutation may be derived characters. Phylogenetic analyses indicate that the last four C-region domains of NAR diverged from an $\mathrm{IgX} / \mathrm{IgW} / \mathrm{NARC} / \mathrm{NAR}$ common ancestor after the $\operatorname{IgM} / \mathrm{IgX}$ divergence but prior to the divergence of the sharks and skates. Presumably, NAR would have existed in a common ancestor of both sharks and rays/skates (23). Alternatively, NAR could represent a chimeric structure, reflecting $C$ terminal elements of $\operatorname{IgX}$ and $\mathrm{a}_{1}$-type domain as well as a $\mathrm{V}$ region of divergent origin.

\section{Light-Chain Genes}

Light-chain genes have been identified in both major radiations of cartilaginous fish. Type I light-chain genes in horned shark and skate cannot be classified as either $\kappa$ or $\lambda$ chains (36). In horned shark, light-chain genes exist in multiple, independently functioning clusters consisting of closely linked single $\mathrm{V}_{\mathrm{L}}$ and $\mathrm{J}_{\mathrm{L}}$ segments, and a $\mathrm{C}_{\mathrm{L}}$ exon (37). The type I light-chain genes in horned shark possess a typical regulatory octamer (37), and germline joining has not been detected. In contrast, a multisite PCR priming strategy and analyses of genomic clones in the little skate failed to identify any unjoined type I light-chain genes. Several of these germline-joined genes are expressed and appear to undergo somatic mutation $(8,38)$.

Type II light-chain genes have been characterized in sandbar shark (39-41), two different skate species (42), and ratfish (14). Genomic cloning and PCR analyses suggest that type II light-chain genes in the sandbar shark are germline-joined (40) and are encoded in clusters that can be classified in two sequence groups (41). All type II light-chain genes in skate are also germline-joined (42). Type II light-chain genes have been shown at the protein level to associate with IgM heavy chains in clearnose skate (Raja eglanteria) (M Anderson, unpublished observations). Unlike the heavy-chain genes in the cartilaginous fish, light-chain genes of a given type within a species are either 
completely joined or unjoined. Although type I genes can be joined (skate) or unjoined (shark), type II genes are joined in sharks, skates, and ratfish, confounding definition of any simple pattern for the acquisition of the joined character. However, the observations are consistent overall with germline joining being a derived characteristic.

Attempts to classify type I and II light-chain genes relative to $\kappa$ - or $\lambda$-type are complicated by the large phylogenetic distances between the cartilaginous fish and the higher vertebrate prototypes, as well as the relatively rapid rates of evolution of antigen binding receptors. However, the type I genes certainly are unlike those of higher vertebrates. The classification of a third type of light chain found in the nurse shark (43) and horned shark (42) as $\kappa$-like is well supported by phylogenetic analyses $(43,44)$. The $\kappa$-like genes are not germline-joined. The distinctive character of the three families of Ig light-chain genes will facilitate studies of potential isotypic exclusion.

\section{IMMUNOGLOBULIN GENES IN RAY-FINNED FISH}

\section{Heavy-Chain Genes}

Unlike the organization of heavy-chain genes in the cartilaginous fish, an IgM heavy-chain gene is encoded at a single mammalian-like locus in representative species of the chondrostean, holostean, and teleost radiations of the ray-finned fish (Figure 1c). The IgM loci in teleosts such as ladyfish (Elops saurus), channel catfish (Ictalurus punctatus), Southern pufferfish (Spheroides nephelus), and rainbow trout (Oncorhynchus mykiss) consist of multiple $\mathrm{V}_{\mathrm{H}}, \mathrm{D}_{\mathrm{H}}$, and $\mathrm{J}_{\mathrm{H}}$ elements linked to IgM $\mathrm{C}_{\mathrm{H}}$ exons that are linked within $\sim 100 \mathrm{~kb}$. Shorter intersegmental $\left(\mathrm{V}_{\mathrm{H}}-\mathrm{D}_{\mathrm{H}}\right)$ distances are found in teleost fish Igs than are found in mammalian Igs $(45,46)$.

The constant regions of IgM heavy chains in teleosts are encoded by four $\mathrm{C}_{\mathrm{H}}$ and two TM exons that are related to IgM heavy-chain genes in higher vertebrates. However, differences have been noted in cysteine distributions and potential glycosylation patterns $(47,48)$ as well as in the relative hydropathicity of the $\mathrm{C}_{\mathrm{H}} 3$ domain(s) relative to $\mathrm{C}_{\mathrm{H}} 3$ in IgM heavy chains of other vertebrates (47). TM exons have been shown to be spliced directly into $\mathrm{C}_{\mathrm{H}} 3$, producing a shorter membrane-bound form of heavy chain $(48,49)$. The phenomenon is tissue independent and may be generalized in the teleost fish (50). Both the $\mathrm{C}_{\mathrm{H}} 3$ to-TM mode of differential processing found in teleost fish and the $\mathrm{C}_{\mathrm{H}} 4$-to-TM pattern found in sharks, amphibians, and mammals (14) are found in the bowfin (Amia calva), a representative of the holostean lineage that diverged prior to the lineage that included the latest common ancestors of the teleosts (Figure 1c) (51). Ig accessory molecules, which possibly relate to signal transduction molecules found in higher vertebrates, are associated with the membrane form 
of Ig in catfish (52). Studies of enhancer function in catfish B cell lines have revealed that the Ig heavy-chain enhancer lies downstream of $\mathrm{C}_{\mathrm{H}} 4$ and not in the $\mathrm{J}-\mathrm{C}$ intron. It is possible that enhancer function had to arise in the $\mathrm{J}$-C intron as a precondition to the emergence of class switching in order to avoid deletion of the enhancer during the switch recombination event (53).

The potential for generating $\mathrm{V}_{\mathrm{H}}$ gene diversity by combinatorial joining in ray-finned fish is considerable. In catfish, seven different $V_{H}$ families, multiple $\mathrm{D}$ segments, and at least nine $\mathrm{J}_{\mathrm{H}}$ segments, which are linked within $1.9 \mathrm{~kb}$ to $\mathrm{C}_{\mathrm{H}} 1$, have been described (54). Trout encode at least $11 \mathrm{~V}_{\mathrm{H}}$ gene families and $10-20 \mathrm{D}_{\mathrm{H}}$ segments $(55,56)$; rearrangement joins in CDR3 are relatively short by comparison with mammals. Although the reduced length complicates assessment of $\mathrm{D}_{\mathrm{H}}$ contributions, there is no direct evidence that the short CDR3 lengths compromise antibody diversity (57).

A second class of Ig heavy-chain gene, which encodes an $\operatorname{IgM~}_{\mathrm{H}} 1$ domain plus seven additional $\mathrm{C}_{\mathrm{H}}$ exons, is contiguous with the IgM heavy-chain gene in catfish. A similar situation has been observed in the pufferfish; however, the second isotype contains only six additional $\mathrm{C}_{\mathrm{H}}$ exons (T Ota, $\mathrm{C}$ Amemiya, personal communication). The extent of amino acid sequence identity between the second fish isotype and corresponding mouse and human $\operatorname{IgD}$ exons is quite low; however, identity between some $\mathrm{C}_{\mathrm{H}}$ exons in mouse and human $\operatorname{IgD}$ is also very low (58). The chromosomal location of the $\operatorname{IgM}$ and $\operatorname{IgD}$ like exons, the predicted alternative splicing, the separate secretory and TM domains, and the coexpression with IgM ( $\mu$-type) heavy chains in some B cells support a relationship of the catfish gene to IgD but a hinge region, such as that found in $\operatorname{IgD}$, is not present. The difference in gene organization between the cartilaginous and ray-finned fish is extreme. Although subsequent radiations of vertebrates preserved the overall mammalian-like organization of the Ig heavychain gene locus seen in the ray-finned fish, changes have taken place in its form and function that underscore the unusually fluid character of Ig gene evolution.

\section{Light-Chain Genes}

The chondrostean radiation, represented by the sturgeon (Acipenser), is the most distant lineage of the ray-finned fish relative to the teleosts (Figure 1c). In this species, multiple $\mathrm{V}_{\mathrm{L}}$ genes are encoded upstream of $\mathrm{J}_{\mathrm{L}}$ sequences and a single (or relatively few) $\mathrm{C}_{\mathrm{L}}$ region(s), a pattern that is distinct from the organization patterns described in the teleosts (59) and reminiscent of the $\kappa$ light-chain gene locus in mammals. In contrast, Southern blot analyses suggest that one form of Ig light-chain (IgLC1) gene in two teleost species, trout and Atlantic cod (Gadus morhua), is organized in a cluster-type organization, similar to the cluster-type I (unjoined) light-chain genes in horned shark (60); however, in teleost fish, the individual clusters are closely linked $(60,61)$. A second 
light-chain isotype in trout (IgLC2), which is only distantly related to IgLC1, also exhibits cluster-type organization. Two repeat sequences that are found upstream of mammalian $\mathrm{J}_{\kappa}$ and may represent transcription factor binding sites were identified in sterile IgLC2 transcripts (62). In catfish, two classes of light chains designated $\mathrm{G}$ and $\mathrm{F}$, which share $52 \%$ and $34 \%$ amino acid identity in the $\mathrm{V}$ and $\mathrm{C}$ regions, respectively, have been identified. The $\mathrm{V}_{\mathrm{F}}$ region is present in multiple families and is homologous to higher vertebrate $\mathrm{V} \kappa$, and $\mathrm{V}_{\mathrm{G}}$ is closely related to IgLC1. $\mathrm{C}_{\mathrm{G}}$ and $\mathrm{C}_{\mathrm{F}}$ domains cannot be unequivocally assigned to other vertebrate light-chain classes $(60,61,63)$. Southern blot analyses are consistent with at least $15 \mathrm{G}$ clusters and more than $50 \mathrm{~F}$ clusters. The $\mathrm{G}$ loci consist of at least two $\mathrm{V}_{\mathrm{G}}$ elements upstream of two $\mathrm{J}_{\mathrm{G}}$ elements, one of which is likely to be a pseudogene, and a single $\mathrm{C}_{\mathrm{G}}$ exon. $\mathrm{F}$ loci resemble basic $\mathrm{V}_{\mathrm{L}}-\mathrm{J}_{\mathrm{L}}-\mathrm{C}_{\mathrm{L}}$ cartilaginous fish-like light-chain clusters. As in the $G$ cluster, the $V_{F}$ and $J_{F}$ segments are in opposite transcriptional polarity, indicating rearrangement by inversion rather than by deletion $(61,63)$. Neither type of cluster is associated with germline joining. The close linkage of the individual clusters could permit intercluster recombination, although this has not been demonstrated. The relationships among light-chain gene organization patterns in the cartilaginous fish, the sturgeon, and several different teleost lineages cannot be reconciled in a simple model (59).

\section{IMMUNOGLOBULIN GENES IN THE LOBE-FINNED FISH}

\section{Heavy-Chain Genes in a Living Fossil}

Different forms of organization of Ig heavy-chain genes are associated with different mechanisms of somatic diversification and regulation of gene expression. Specifically, combinatorial rearrangement of segmental elements does not appear to be used to diversify gene clusters in cartilaginous fish (18). Furthermore, unlike Ig gene loci in higher vertebrates, gene rearrangement per se is not an obligate requirement $(7,8,39,40)$. The living coelacanth (Latimeria chulumnae) is a surviving member of an ancient superorder that was long thought to be extinct (Figure $1 c$ ). $\mathrm{V}_{\mathrm{H}}$ and $\mathrm{D}_{\mathrm{H}}$ segments in coelacanth Ig heavy-chain genes are linked closely ( $\sim 190 \mathrm{bp})$, a similar character to that described in the cartilaginous fish (64). The V-D pairs themselves are in close tandem linkage (3-4 kb), presumably upstream of $\mathrm{J}_{\mathrm{H}}$ and $\mathrm{C}_{\mathrm{H}}$. The putative coding regions of $\mathrm{D}_{\mathrm{H}}$ contain recombination signal sequences (RSSs) with 12-bp spacers and are related to a "join" of shark-type $\mathrm{D}_{\mathrm{H}} 1$ and $\mathrm{D}_{\mathrm{H}} 2$ (7). The apparent absence of additional $\mathrm{D}_{\mathrm{H}}$ segments (and RSSs) downstream of V-D is consistent with precommitted joining of V-D pairs. Southern blotting of coelacanth DNA using a $\mathrm{V}_{\mathrm{H}^{-}}$-specific 
probe reveals a large number of hybridizing elements. All of the genomic $\mathrm{V}_{\mathrm{H}}$ genes thus far sequenced are members of a single family; cDNA analyses will be required to further assess $\mathrm{V}_{\mathrm{H}}$ family divergence and to characterize $\mathrm{J}_{\mathrm{H}}$ and $\mathrm{C}_{\mathrm{H}}$ contributions.

\section{Heavy-Chain Gene Isotype Diversity}

Modern lungfish are a critical group in terms of understanding possible distinctions between Ig genes in ray-finned fish and in representatives of the phylogenetic radiation that includes the ancestors of the amphibian and reptiles (Figure $1 d$ ). Three distinct heavy-chain cDNAs have been identified in African lungfish (Protopterus aethiopicus): (a) an IgM gene encoding four $\mathrm{C}_{\mathrm{H}}$ region domains, $(b)$ a second type encoding seven $\mathrm{C}_{\mathrm{H}}$ domains, and $(c)$ a third type encoding two $\mathrm{C}_{\mathrm{H}}$ domains and a $3^{\prime}$ cysteine-rich domain, similar to that in an avian IgY gene (see below). The seven $\mathrm{C}_{\mathrm{H}}$ domain-containing genes resemble the IgD-like gene in the ray-finned fish discussed above; however, $\mathrm{C}_{\mathrm{H}} 1$ is not IgM-like. Six distinct $\mathrm{V}_{\mathrm{H}}$ families have been identified in lungfish (65) (T Ota, C Amemiya, personal communication). By analogy to avians and through general phylogenetic inference, it is possible that the heavy-chain gene class switch arose prior to the divergence of the lungfish and tetrapods. Light-chain gene structures have not been described for either the coelacanth or lungfish.

\section{IMMUNOGLOBULIN GENES IN AMPHIBIANS}

\section{Heavy-Chain Genes}

In addition to their phylogenetic position, amphibians are of particular significance as an immunological model system that undergoes metamorphosis (66). The Ig heavy-chain gene locus in the African clawed frog (Xenopus laevis), an anuran amphibian, encodes three types of $\mathrm{C}$ regions: $\operatorname{IgM}, \operatorname{IgX}$, and IgY. The TM regions of IgX and IgY are more closely related to the TM regions of Xenopus IgM than to mammalian forms, supporting a hypothesis that $\operatorname{IgM}$ duplicated to give rise to $\operatorname{IgY}$ and $\operatorname{IgX}$ (67), which is not related to $\operatorname{IgX}$ in cartilaginous fish but rather is considered to be an IgA functional equivalent (68). No evidence has been found, in either developing or mature lymphocytes, for IgD-like genes or for alternative splicing of $\mathrm{C}_{\mathrm{H}}$ regions. Amphibians are the most divergent species relative to the mammals (Figure 1a), in which a mammalian-type heavy-chain class-switching mechanism has been documented, although this characteristic could be present in lobe-finned fish (Figure 2). The $\mu$-type switch region (S) in Xenopus is $\sim 5 \mathrm{~kb}$ and consists of 23 repeats of $\sim 150 \mathrm{bp}$; each repeat consists of shorter internal repeats and palindromic sequences. Class switching occurs after gene rearrangement and is greatly accelerated in the secondary immune response. In IgX-expressing B 
cells, the $\mu$-type heavy-chain gene is deleted and $\mathrm{S} \mu$ and $\mathrm{Sx}$, which are not related at the sequence level, are joined. As in mammals, switching recombination occurs at microsites formed through repetitive palindromes and is associated with tissue-specific gene expression (69).

Eleven different $\mathrm{V}_{\mathrm{H}}$ gene families, extensively diversified $\mathrm{D}_{\mathrm{H}}$ genes, and a high level of $\mathrm{J}_{\mathrm{H}}$ diversity are found in Xenopus (70-72). Certain $\mathrm{V}_{\mathrm{H}}$ families have multiple members and all but the $\mathrm{V}_{\mathrm{H}} \mathrm{III}$ and $\mathrm{V}_{\mathrm{H}} \mathrm{VII}$ families have been found to be interspersed (73). Multiple $5^{\prime} \mathrm{Ig}$ regulatory octamer sequences and octamer-like motifs are found upstream of Xenopus $\mathrm{V}_{\mathrm{H}}$ genes, which suggests that their regulation could have unique features $(70,73)$. Restricted utilization of $\mathrm{D}_{\mathrm{H}}$ sequences and limited $\mathrm{N}$ region diversity are associated with early development in Xenopus (74).

Axolotol (Ambystoma mexicanum) is a neotenic amphibian, i.e. the mature form of the animal retains larval features. Both IgM and IgY have been identified in axolotol. In axolotol IgY, additional cysteines, as have been found in Xenopus $\mathrm{C}_{v}$, avian $\mathrm{C}_{v}$, and human $\mathrm{C}_{\varepsilon}$, are found in the $\mathrm{C}_{v} 1$ and $\mathrm{C}_{v} 2$ regions. The IgY molecule in axolotol is secretory (75).

Three axolotol Ig $\mathrm{V}_{\mathrm{H}}$ families as well as four $\mathrm{D}_{\mathrm{H}}$ and six $\mathrm{J}_{\mathrm{H}}$ elements have been identified $(75,76)$. Analyses of spleen Ig cDNAs reveal greater numbers of out-of-frame sequences in early embryos than at later developmental stages. A slight increase in the length of CDR3 between subadult and adult axolotols has been reported (77). The CDR3 loop of axolotol $\mathrm{V}_{\mathrm{H}}$ genes has been interpreted to be less somatically diversified than CDR3 in any developmental stage of mouse or Xenopus. The discovery that $\mathrm{V}_{\mathrm{H}}$ regions in axolotol have both shorter junctional sequences and extensive conservation of the germline $\mathrm{J}_{\mathrm{H}}$ sequences possibly relates to the decreased affinities in antibody responses in this species compared with Xenopus and teleost fish (78).

\section{Light-Chain Genes}

Three classes of light-chain genes have been identified in Xenopus (79-81). The $\rho$ locus contains at least four $\mathrm{V}_{\rho}$ and five $\mathrm{J}_{\rho}$ elements as well as a single $\mathrm{C}_{\rho}$ gene and is classified as $\kappa$-like on the basis of both $\mathrm{V}_{\rho}$ sequences and organizational features of the $\rho$ locus $(44,80)$. The $\sigma$-type light chain consists of multiple $\mathrm{V}_{\sigma} 1$ and $\mathrm{V}_{\sigma} 2$ as well as $\mathrm{C}_{\sigma} 1$ and $\mathrm{C}_{\sigma} 2$ segments (79); both types of genes rearrange to their respective $\mathrm{J}_{\sigma}$ types. The $\sigma$ and $\rho$ genes are encoded at separate loci. Expressed $\mathrm{V}_{\sigma}$ sequences are highly conserved and diversity of $\sigma$ and $\rho$ light-chain genes in Xenopus may be markedly restricted, as opposed to the heavy-chain genes, which are as diversified, if not more so, than their mammalian counterparts (72).

A third light-chain type in Xenopus represents a higher vertebrate $\lambda$ lightchain homolog. Six distinct $V_{\lambda}$ families, two $J_{\lambda}$ segments, and two distinct $C_{\lambda}$ 
exons have been characterized. Southern blotting of DNA as well as sequence analysis from individual animals indicates that the $V_{\lambda}$ and $C_{\lambda}$ sequences are diverse and polymorphic (81). The complex diversity in the $\lambda$-type light-chain genes argues against diversity restriction in the overall light-chain repertoire in Xenopus.

\section{IMMUNOGLOBULIN GENES IN REPTILES}

\section{Heavy-Chain Genes}

Southern blotting of reptilian [caiman (Caiman crocodylus) and turtle (Chelydra serpentina)] DNAs indicates large numbers of $\mathrm{V}_{\mathrm{H}}$ genes that cross hybridize with murine and species-specific $\mathrm{V}_{\mathrm{H}}$ probes (82) (G Litman, unpublished observation). Screening of a single genomic equivalent of a turtle genomic $\lambda$ DNA library using homologous $\mathrm{V}_{\mathrm{H}}$ probes resulted in hybridization to $>500$ individual clones. At the stringency used, the hybridizing elements could be as little as $60 \%$ related to the probe used for screening. Each $\lambda$ genomic clone typically consists of multiple, linked $\mathrm{V}_{\mathrm{H}}$ genes; however, many of the hybridizing bands may represent pseudogenes. Overrepresentation of individual clones does not account for the large number of positives. In situ chromosomal hybridization mapped turtle genes to four separate linkage groups (26) (C Amemiya, G Litman, unpublished observation). More recent studies in another species of turtle (Pseudemys scripta) defined four families of $\mathrm{V}_{\mathrm{H}}$ genes, which are encoded at a single $\mu$-type locus (83). Northern blot analyses using ${ }^{a} \mathrm{C}_{\mathrm{H}} 4$ probe identified two $\mu$-type transcripts and at least two non- $\mu$-type transcripts. Analyses of rearranged Ig heavy-chain gene transcripts from a single animal suggest large numbers of $\mathrm{J}_{\mathrm{H}}$ segments and/or extensive somatic mutation in FR4. In terms of the generation of antibody diversity, it is apparent that reptiles contain particularly large numbers of $\mathrm{V}_{\mathrm{H}}$ genes. Although avians technically are members of the reptilian radiation of vertebrates, their Ig genes represent a marked departure from the typical reptilian organization, as defined in caiman and turtles.

\section{IMMUNOGLOBULIN GENES IN AVIANS}

\section{Heavy-Chain genes}

The chicken (Gallus domesticus) is the most comprehensively characterized nonmammalian immunological model system (84-86). Three classes of heavychain genes are present in this species. Class switching occurs from IgM to either IgY or IgA; IgM to IgY switching occurs during the secondary antibody response and is associated with increased antibody affinity (see below). In addition to $\operatorname{IgM}$ and $\operatorname{IgA}(87)$, two forms of $\operatorname{IgY}$, possessing nearly identical $\mathrm{C}_{\mathrm{H}} 1$ 
and $\mathrm{C}_{\mathrm{H}} 2$ domains, are present in the duck Anas platyrhynchos (88). The shorter transcript encodes $\mathrm{C}_{\mathrm{H}} 1$ and $\mathrm{C}_{\mathrm{H}} 2$ plus a unique short exon encoded between $\mathrm{C}_{\mathrm{H}} 2$ and $\mathrm{C}_{\mathrm{H}} 3$. The longer transcript encodes $\mathrm{C}_{\mathrm{H}} 1-\mathrm{C}_{\mathrm{H}} 4$ in either secretory or TM forms. On the basis of inferred intrachain disulfides and the number of secretory exons, the full-length form of IgY resembles IgE; however, TM sequences and similar RNA processing are more characteristic of IgG, which suggests that IgG and $\operatorname{IgE}$ diverged from a common ancestral molecule resembling $\operatorname{IgY}(89,90)$.

Chickens possess a $>60-80 \mathrm{~kb}$ heavy-chain gene locus consisting of a single functional $\mathrm{V}_{\mathrm{H}}$ gene, 16 relatively similar $\mathrm{D}_{\mathrm{H}}$ segments, and a single $\mathrm{J}_{\mathrm{H}}$ element, which are arrayed upstream of the $\mathrm{C}_{\mathrm{H}}$ region genes $(84,91)$. Only limited combinatorial diversity and little junctional diversity is achieved through differential rearrangement of $\mathrm{D}_{\mathrm{H}}$ segments. The principal means of diversification is achieved through gene conversion that utilizes a pool of 80-100 5 '-truncated upstream $\mathrm{V}_{\mathrm{H}} \Psi$ (pseudogenes), which lack RSSs and are in different relative transcriptional polarities. Certain $\mathrm{V}_{\mathrm{H}} \Psi$ possess $\mathrm{D}_{\mathrm{H}^{-}}$-like and $\mathrm{J}_{\mathrm{H}^{-}}$like sequences at the $3^{\prime}$ ends, and gene conversion can extend into these regions; preferred $\mathrm{V}_{\mathrm{H}} \Psi$ exchanges have also been described (92). Furthermore, a high incidence of $\mathrm{D}_{\mathrm{H}}-\mathrm{D}_{\mathrm{H}}$ joining and $\mathrm{P}$ nucleotide addition also diversifies the $\mathrm{V}_{\mathrm{H}}$ locus (92). Given the phylogenetic positions of avians as having diverged from a common ancestor with the reptiles after the divergence of the mammals, the avian Ig heavy-chain gene presumably is a derived evolutionary character. Gene conversion also has been documented unequivocally in one mammal (93) and presumably occurs in others (94-96).

\section{Light-Chain Genes}

The somatic hyperconversion process described above was characterized initially for the single $\lambda$-like light-chain locus of the chicken $(97,98)$. Twenty-six $\mathrm{V}_{\mathrm{L}} \Psi$ are upstream of single, closely linked $\mathrm{V}_{\mathrm{L}}$ and $\mathrm{J}_{\mathrm{L}}$ segments $(97,99)$. A variant of this arrangement, in which the pseudogenes are upstream of two functional $\mathrm{V}_{\mathrm{L}}$ segments, has been described in another avian species (100). The frequency of $\mathrm{V}_{\mathrm{L}} \Psi$ use depends on the proximity of the pseudogene and target genes as well as the extent of identity and their relative orientation. Homology in the $5^{\prime}$ pseudogene and target is most essential and evidence for polarity in the gene conversion mechanism(s) has been presented (101). In addition to gene conversion, a number of mechanisms, including imprecise joining, somatic point mutation, single nonrandom nucleotide additions (102), and V gene replacement (99), further diversify light-chain genes.

The diversification mechanisms found in avians are of particular interest from an evolutionary standpoint in terms of the stability and maintenance of $\mathrm{V} \Psi$ (donors). Comparisons of $\mathrm{V}_{\mathrm{L}} \Psi$ and functional alleles between three inbred lines of chicken identified multiple interstrain polymorphisms as well as 
polymorphisms that could arise by meiotic gene conversion. The incidence of mutations within the $\mathrm{V}_{\mathrm{L}} \Psi$ is lower than in the corresponding flanking regions, consistent with the hypothesis that the $\mathrm{V}_{\mathrm{L}} \Psi$ cluster behaves as a functional multigene family under selective pressure for its role in the diversification of the antibody repertoire (103). The similarities between the organization of the Ig heavy- and light-chain loci in both avian and cartilaginous fish models suggests parallel evolution of both form (organization) and function (mechanisms of diversification) in antigen binding receptors (37).

\section{PHYLOGENETIC ORIGINS OF SOMATIC HYPERMUTATION}

Targeted somatic hypermutation has been demonstrated in all vertebrate Ig gene systems thus far examined (11) and is undoubtedly an ancient mechanism for the diversification of the antigen-binding sites of Igs, regardless of their genomic organization (8). The degree of somatic hypermutation varies by approximately an order of magnitude among vertebrate groups (11). Somatic hypermutation in mammals is associated with affinity maturation (10), which can be several orders of magnitude greater than in anuran amphibians and teleost fish. Temporal increases in antibody affinity have not been observed in cartilaginous fish $(18,104)$. The discrepancy between the presence of somatic hypermutation and the absence of affinity maturation in the cartilaginous fish is difficult to reconcile. One explanation is that the absence of germinal centers in cartilaginous fish may result in a lower efficiency of cellular selection of high-affinity mutants $(10,18,105)$. However, this supposition raises the question of why targeted somatic mutation would have evolved prior to the development of a selection system. One possibility is that somatic mutation could diversify the preimmune repertoire prior to selection, as occurs in sheep Peyer's patches (106). However, recent studies indicate that NAR mutations are accumulated after exposure to antigen and are not used to generate the preimmune repertoire (35), which argues against this theory. Although the basis for mutation of the shark NAR gene could be different from the other cluster-type genes, this observation is consistent with NAR mutations being a shared character with mammalian somatic mutation and, thus, ancestral. It is possible that rather than repeated rounds of mutation and expansion in response to antigen receptor signaling, as occurs in mammalian germinal centers (107), lymphocytes in lower vertebrate groups are biased toward terminal differentiation. It is also possible that highaffinity mutants reside in other (unknown) tissue(s) in these animals. Further study is required to relate differences in antigen binding receptor structures in various vertebrate groups to the differences observed in immune function assays. 


\section{B CELL MEMORY AND THE SECONDARY IMMUNE RESPONSE}

The evolution of antigen binding receptors involves organizational and mechanistic change and occurs within the context of highly specialized systems that potentiate function of effector molecules. B and T cell memory, defined in terms of the ability to respond more rapidly and effectively to secondary challenge with a specific antigen, are found in all jawed vertebrates, with the possible exception of the cartilaginous fish (66). Specifically, upon secondary antigenic challenge, horned sharks do not show a dramatic rise in levels of antibody. Rather, the increase requires repeated monthly immunizations and occurs over a much longer time interval than is seen in mammals $(108,109)$.

Both teleost fish and amphibians demonstrate a secondary rise in antibody levels that is greater and more rapid than the primary response, but less vigorous than that seen in mammals. The secondary response is generally 10 - to 20 -fold higher than the primary response, without a measurable increase in affinity. It has been shown that a low priming dose is required to achieve optimal memory development in carp (Cyprinus carpio) (110). Whether IgM memory in mammals exists is debatable, and thus the role of isotype switching in triggering changes characteristic of the memory response is unclear. The modest secondary response consisting primarily of IgM antibody, which is seen in teleost fish, indicates that a limited form of memory exists in the absence of class switching.

Anuran amphibians (such as Xenopus) exhibit a peak in the primary response at 4 weeks. The secondary response peak occurs at 2 weeks postimmunization and is accompanied by class switching from IgM primarily to IgY. The secondary response is associated with 10-40 times greater antibody production (111). However, in urodele amphibians [such as the newt (Notophthalmus viridescens)] class switching does not appear to occur. The peak level of antibody in response to T-dependent antigens does not increase in the secondary response, although the rise in antibody occurs more rapidly (112).

Current views on mammalian memory emphasize the importance of the affinity of antigen receptor-antigen interactions in controlling which signaling pathways are activated and, thus, how the functional response is modulated (113). A strong-affinity interaction results in a full activation of all possible signaling pathways, leading to activation of the effector function gene expression program. However, a low-affinity interaction results in partial activation, which sensitizes the cell to further stimulation without inducing proliferation or effector function and allows entry into the memory compartment. Studies of memory B cells (114) support a model in which clonal expansion occurs primarily in cells that are undergoing the effector program response, not in cells that are 
fated to become memory cells. The observation that a low priming is needed to achieve memory development in carp whereas high-priming doses result in poor memory responses suggests a similar mechanism in the development of memory in teleost fish (110). Two key differences between cartilaginous fish and higher vertebrate immunity are the low-affinity Ig receptors that do not mature, and the apparent lack of sensitization leading to a memory response. It is difficult to understand how the shark lymphocytes, which bear low-affinity antigen receptors, become activated to a full effector response unless there are major differences in the way their antigen receptors interact with the signaling apparatus, or unless there is a significant change in the signaling threshold.

\section{THE IDENTIFICATION OF T CELL ANTIGEN RECEPTOR HOMOLOGS IN NONMAMMALIAN VERTEBRATES}

T cell-mediated immunity was thought to exist in all the phylogenetic groups in which rearranging Ig genes were known to exist. However, with the exception of chicken TCR $\beta$ (115), nonmammalian TCRs have proven refractory to isolation by DNA cross hybridization strategies that were used successfully to identify Ig genes in lower vertebrates. The primary basis for this technical disparity most likely relates to the higher rates of sequence divergence among TCRs. High rates of divergence are characteristic of immune genes relative to their nonimmune counterparts (116). The forces driving this rapid divergence are unclear but could stem from a generally lower level of constraint on immune proteins. Alternatively, this rate could result from sequence divergence in response to interactions with molecules—-such as the TCRs themselves and MHC proteins - that are under heavy positive selection to vary (117). Paradoxically, as more data are acquired, it appears that although TCR genes are generally diverged in primary sequence, TCRs may be more conserved than Igs in terms of gene organization, diversification mechanisms, and subclass heterogeneity.

\section{T CELL ANTIGEN RECEPTOR GENES IN CARTILAGINOUS FISH}

The particular interest in TCR genes in cartilaginous fish relates not only to their phylogenetic position but also to functionally unique aspects of immunity in these species, e.g. apparent absence of affinity maturation and chronic allograft rejection (118). A PCR strategy based on shared 3-4 amino acid motifs in FR2 and FR3 of higher vertebrate TCR and $V_{L}$ genes of higher vertebrates (119) was used to amplify candidate gene segments using horned shark cDNA as template. 
Sequence analyses of cDNAs selected with the candidate segments identified clones with $\mathrm{V}, \mathrm{J}$, and $\mathrm{C}$ regions that were most $\mathrm{TCR} \beta$-like. Comparisons of cDNA clones reveal $(a)$ a $\mathrm{D} \beta$ region core element and $(b)$ that combinatorial joining plays a role $\mathrm{TCR} \beta$ diversification in shark. Genomic $\mathrm{V} \beta$ and $\mathrm{J} \beta$ region sequences were shown to have typical RSS elements separated by 23-bp (V) and 12-bp (J) spacers, respectively (119). Southern blotting indicates that $\mathrm{V} \beta$ and $\mathrm{C} \beta$ gene elements are present in multiple copies yet are organized (unlike the shark Ig heavy-chain genes) in several tandem arrays consisting of multiple $\mathrm{V} \beta$ and $\mathrm{J} \beta$ elements, similar to mammalian TCR genes. The differences in restriction enzyme digestion patterns of genomic lambda clones containing $\mathrm{C} \beta$ Ig domain exons and cDNA analyses are consistent with multiple $\mathrm{C} \beta$ region genes (120). However, this multiplicity may not be the rule for TCR genes in cartilaginous fish, as the four classes of TCR genes that have been identified thus far from the skate (see below) are encoded in one or at most two copies (121).

Additional information about $\mathrm{V} \beta$ diversity in horned shark has been obtained by sequencing large numbers of spleen TCR $\beta$ cDNAs. Seven $\mathrm{V} \beta$ families, 18 different $\mathrm{J} \beta$ sequences, and a putative $\mathrm{D} \beta$ core sequence (GGGACAAC) were identified (120). Phylogenetic analyses comparing the shark $\mathrm{V} \beta$ sequences to those of other vertebrates suggest that at least some $\mathrm{V} \beta$ family divergence occurred prior to the divergence of the cartilaginous fish and the lineage leading to mammals.

Two TCR $\delta$-like genes have been identified in horned shark (122). Initially it was unclear whether these genes represented a TCR $\delta$ ortholog; however, the later identification of homologs of TCR $\alpha$ and TCR $\delta$ in the skate (121) and the relationship of these genes to the horned shark genes suggest that the $\alpha / \delta$ divergence occurred prior to or early in jawed vertebrate evolution. The two related but divergent TCR $\delta$ homologs as well as the multiple TCR $\beta$ loci may relate to genomic polyploidy in horned shark (122).

Determination of orthology among mammalian and cartilaginous fish TCR genes is problematic given the divergent nature of TCR genes. A more comprehensive, though by no means exhaustive, approach based on short primer PCR was used to amplify TCR genes from the clearnose skate (121), a welldefined developmental model (123). cDNAs were identified that are similar to the four mammalian TCR gene types in terms of $\mathrm{V}$ and $\mathrm{C}$ region sequence, absence or presence (inferred) of D regions, and other junctional characteristics. TM regions associated with each of the four TCR types conform to conserved antigen receptor TM motifs described in higher vertebrates (124). Sequencing of representatives of the different $\mathrm{V}$ families for each putative gene type is completely consistent with TCR $\alpha, \beta, \gamma$, and $\delta$ orthology. Specifically, four skate $\mathrm{V} \alpha$ and six distinct $\mathrm{J} \alpha$ region families were identified. TCR $\alpha$ 
junctional sequences are short, consistent with direct V-J joining. Six skate V $\beta$ region families, two potential $\mathrm{D} \beta$ core elements, and four $\mathrm{J} \beta$ region families are associated with the $\mathrm{C} \beta$ homolog. Although each of the $\mathrm{D} \beta$ s is G-rich, neither is otherwise similar to the putative $\mathrm{D} \beta$ region identified from horned shark TCR $\beta$. Five $\mathrm{V} \gamma$ and two $\mathrm{J} \gamma$ families were identified and direct $\mathrm{V} \gamma \mathrm{J} \gamma$ joinings were observed, although some cDNAs possess more complex junctions. Five V $\delta$ and two $\mathrm{J} \delta$ families have been identified. Three potential $\mathrm{D} \delta$ core elements are present in TCR $\delta$ VJ junctions. The long junctional lengths are characteristic of mammalian TCR $\delta$ genes. Pulsed field gel analyses suggest that $\mathrm{C} \alpha$ and $\mathrm{C} \delta$ are linked, although the distance between the elements is probably considerably greater than in mammals.

\section{T CELL ANTIGEN RECEPTOR GENES IN RAY-FINNED FISH}

TCR genes have been described from four representative species of ray-finned fish. A TCR $\beta$ gene from the rainbow trout was cloned using a degenerate PCR amplification strategy with primers that targeted conserved $\mathrm{V}$ sequence motifs (125). The sequences of amplified products were used to generate specific primers, and an anchor PCR strategy employing thymocyte cDNA as template was used to clone a corresponding $\mathrm{C} \beta$ region. Three trout $\mathrm{V} \beta$ families, exhibiting between $30 \%$ and $38 \%$ pairwise amino acid identity, and 10 different $\mathrm{J} \beta$ sequences were described (126). The $\mathrm{J} \beta$ segments possess canonical $5^{\prime} 7$-mer elements, and although a number of these lack typical 9-mers, they are utilized frequently in TCR rearrangements (127). A core $\mathrm{D} \beta$-like sequence (GGACAGGG) in trout is identical to a corresponding sequence in axolotol, chicken, and mouse $\mathrm{D} \beta$ regions. Genomic analyses show that the $\mathrm{D} \beta$ segment in trout is flanked by typical RSS elements. Although Southern blotting analyses potentially indicate multiple $\mathrm{C} \beta$-hybridizing elements, only a single $\mathrm{C} \beta$ sequence was identified. Junctional lengths of the in-frame trout TCR $\beta$ CDR3 regions are somewhat shorter than those observed in mice and chickens and can be accounted for by the relatively short (eight nucleotide) $\mathrm{D} \beta$. Approximately $40 \%$ of trout $\mathrm{D} \beta-\mathrm{J} \beta$ junctions lack N-region nucleotide additions compared with $26 \%$ in the mouse.

The TCR $\beta$ VDJ junctions, along with a portion of $\mathrm{C} \beta$, have been recovered from Atlantic salmon (Salmo salar) using reverse transcription-PCR and leukocyte cDNA as template (128). Only one $\mathrm{C} \beta$ region, closely related to trout $\mathrm{C} \beta$, has been fully characterized. Minor sequence differences in salmon $\mathrm{C} \beta$ were attributed to allelic variation or Taq error; interpretation of these data is complicated by a recent ancestral tetraploidization event, which is expected to result in two $\operatorname{TCR} \beta$ loci. Eight $\mathrm{J} \beta$ region sequences were isolated, of which 
five can be paired readily with trout $\mathrm{J} \beta$. A single $\mathrm{D} \beta$ core sequence, which is identical to that of trout, has been inferred, along with junctional diversity.

A rainbow trout TCR $\alpha$ homolog has been isolated using anchored PCR and a thymocyte RNA template (129). C $\alpha$-specific primers were used to amplify $\mathrm{V} \alpha-\mathrm{J} \alpha$ regions in a $5^{\prime}$-RACE PCR analysis. Of 40 cDNA sequences analyzed, 6 different $\mathrm{V} \alpha$ families and 32 different $\mathrm{J} \alpha$ segments were identified. The high level of $\mathrm{J}$ diversity is characteristic of TCR $\alpha$. Sequence comparisons of the trout $\mathrm{C} \alpha$ reveal a close match with a Southern pufferfish putative TCR $\alpha$ sequence (122).

The catfish, in which lymphocytes and immunocyte cell lines are well characterized, has proven to be an excellent model system for studying lower vertebrate immune function (130). TCR $\alpha$ and $\beta$ have been identified by V region-directed PCR amplification with degenerate primers from peripheral blood leukocyte cDNA. Three $\mathrm{V} \alpha$ families and a single $\mathrm{C} \alpha$ gene as well as five $\mathrm{V} \beta$ and two $\mathrm{C} \beta$ families were identified. Southern blotting using $\mathrm{V} \alpha$ and $\mathrm{V} \beta$ family-specific probes are consistent with additional genes. Seven different $\mathrm{J} \alpha$ and seven $\mathrm{J} \beta$ regions have been identified, as have two potential $\mathrm{D} \beta$ regions, one of which matches corresponding sequences found in a variety of vertebrate $\operatorname{TCR} \beta$ genes. Analyses of the transcription patterns of these genes in phenotypically characterized catfish $\mathrm{T}$ and $\mathrm{B}$ cell lines is consistent with their assignments.

\section{T CELL ANTIGEN RECEPTOR GENES IN AMPHIBIANS}

The TCR $\beta$ genes of Xenopus were isolated by an anchored PCR strategy employing a DNA template from a spleen/thymus cDNA library (131). The single $\mathrm{TCR} \beta$-like $\mathrm{C}$ region that was identified shares TM region features (124) as well as predicted peptide identity $(31 \%)$ with axolotol TCR $\beta$. Ten different, highly divergent $\mathrm{V} \beta$ gene families and 10 different $\mathrm{J} \beta$ segments have been identified. Two putative $\mathrm{D} \beta$ contributions, one of which matches the trout, axolotol, chicken, and human $\mathrm{D} \beta$ sequences, have been inferred along with a possible third $\mathrm{D} \beta$ sequence, similar to that identified in horned shark. N-region diversification most likely occurs in the rearranged junctional regions. RSS sequences for $\mathrm{V} \beta, 5^{\prime}-\mathrm{D} \beta$, and $\mathrm{J} \beta$ were identified in partially rearranged transcripts and are similar to those found in other TCR genes. Notably, the X. laevis $\operatorname{TCR} \beta$ probes do not cross hybridize with DNA from members of the Xenopus tropicalis species group (131), which diverged $~ 120$ MYA from a common ancestor with the $X$. laevis group. This lack of sequence similarity is unusual among genes of the Xenopus immune system (Ig, MHC, etc) which typically cross hybridize between these species. The finding is an example of the higher rate of sequence divergence for TCR than Ig genes. Although the genomic 
sequence of a putative TCR $\alpha \mathrm{V}$ region from Xenopus has been reported (122), a corresponding cDNA has not been described.

The first TCR gene from a nonamniote was identified in the axolotol using an anchored PCR strategy employing degenerate primers complementing a conserved region in TCR $\beta$ and Ig light-chain $\mathrm{C}$ regions (132). Two closely related $\mathrm{C} \beta$ and two additional $\mathrm{C} \beta$ sequences were identified. Nine different $\mathrm{V} \beta$ families were described, of which the $\mathrm{V} \beta 7.1$ gene is utilized most frequently (133). The junctional regions of $189 \mathrm{~V} \beta 7.1$ cDNAs from animals at 2.5, 10, and 24 months were compared and equivalent numbers of $\mathrm{C} \beta 1$ and $\mathrm{C} \beta 2$ positive transcripts were identified along with nine different $\mathrm{J} \beta$ elements. Three $\mathrm{J} \beta 1$ elements were associated with $\mathrm{C} \beta 1$ and six $\mathrm{J} \beta 2$ elements were associated with $\mathrm{C} \beta 2$. Two different $\mathrm{D} \beta$ elements were identified; $\mathrm{D} \beta 1, \mathrm{~J} \beta 1$, and $\mathrm{C} \beta 1$ elements associate preferentially, as do $\mathrm{D} \beta 2, \mathrm{~J} \beta 2$, and $\mathrm{C} \beta 2$. $\mathrm{D} \beta 2-\mathrm{J} \beta 1-\mathrm{C} \beta 1$ and $\mathrm{D} \beta 1-\mathrm{J} \beta 2-\mathrm{C} \beta 2$ transcripts that could arise by trans- or inversional rearrangements, as well as by rearrangements that skip $\mathrm{J} \beta$ and $\mathrm{C} \beta$ elements, respectively, were also identified. Several $\mathrm{V} \beta-\mathrm{J} \beta$ rearrangements were identified that appear to arise either from direct $\mathrm{V} \beta-\mathrm{J} \beta$ joining or from extensive exonucleolytic trimming. $\mathrm{N}$ region addition increases from $40 \%$ of junctions in the 2.5 -month-old animals, to $73 \%$ in the 10- and 24-month-old animals.

A PCR strategy employing $3^{\prime} \mathrm{V} \alpha$ - and $\mathrm{C} \alpha$-TM specific primers was used to identify a TCR $\alpha$ homolog in the axolotol. Five different $\mathrm{V} \alpha$ families and 14 different $\mathrm{J} \alpha$ elements have been identified. As with $\mathrm{TCR} \beta$ from this species (132), a high fraction of rearrangements are out-of-frame (134).

\section{T CELL ANTIGEN RECEPTOR GENES IN AVIANS}

As indicated above, chicken TCR $\beta$ genes were the first nonmammalian TCR genes to be described (115). Two $\mathrm{V} \beta$ gene families, which have mammalian $\mathrm{V} \beta$ counterparts, were identified that appear to define the chicken TCR2 and TCR3 cell lineages $(135,136)$. A total of six $\mathrm{V} \beta 1$ and four $\mathrm{V} \beta 2$ genes encode the chicken $\mathrm{V} \beta$ repertoire. All $\mathrm{V} \beta$ genes rearrange to a single 14 nucleotide $\mathrm{D} \beta$ element. Four $\mathrm{J} \beta$ segments and a single $\mathrm{C} \beta$ element were identified. The extent of N-region addition increases during development and is consistent with ontogenetic up-regulation of terminal deoxynucleotide transferase (TdT) in the thymus (137). The chicken $\mathrm{D} \beta$ region encodes a glycine residue in all three reading frames that presumably participates in the formation of a CDR3encoded loop structure (137).

The chicken TCR $\alpha$ genes were isolated by a coprecipitation-peptide sequencing strategy employing antibodies to chicken CD3 (138). Multiple $\mathrm{V} \alpha$ and $\mathrm{J} \alpha$ elements are linked to a single $\mathrm{C} \alpha$ region. Two $\mathrm{V} \alpha$ gene families, which exhibit $\sim 24 \%$ amino acid identity, account for all $\mathrm{V} \alpha$ expression by $\mathrm{T}$ cell lines 
(136). Southern blotting is consistent with more than $25 \mathrm{~V} \alpha$ elements as well as multiple $\mathrm{J} \alpha$ elements. Typical RSS configurations are associated with chicken genomic $\mathrm{V} \alpha$ and $\mathrm{J} \alpha$ elements.

In mammalian $\mathrm{TCR} \alpha / \delta$ rearrangements, $\mathrm{V} \alpha$ elements associate with $\mathrm{D} \delta$-J $\delta$ $\mathrm{C} \delta$ at a low but significant frequency. cDNA library screening with $\mathrm{V} \alpha$ and $\mathrm{C} \alpha$ probes identified $\mathrm{V} \alpha^{+} / \mathrm{C}^{-}$clones. Sequencing revealed a putative $\mathrm{C} \delta$ gene exhibiting 33\% amino acid identity with human and mouse $\mathrm{C} \delta$. Northern blot analyses showed that this gene is transcribed in thymus and spleen but is absent in chicken $\alpha \beta \mathrm{T}$ cell lines. Two $\mathrm{V} \delta$ families have been identified, and $\mathrm{C} \delta$ associates with both chicken $\mathrm{V} \alpha$ families (136).

TCR $\gamma$ genes in chicken were isolated by a short primer degenerate PCR strategy using chicken genomic DNA as template, followed by screening of a chicken spleen cDNA library with a candidate $\operatorname{TCR} \gamma$-like amplified product (122). Two different $\mathrm{V} \gamma$ families and a putative $\mathrm{C} \gamma$ region were identified. The extracellular Ig domain of putative chicken $\mathrm{C} \gamma$ exhibits $\sim 31 \%$ identity with mouse $\mathrm{C} \gamma$. A third $\mathrm{V} \gamma$ family was identified and each of the three families consists of eight to ten members (139). Three $\mathrm{J} \gamma$ segments and a single $\mathrm{C} \gamma$ region gene have been described. Transcripts that hybridize with a $\mathrm{C} \gamma$ probe are prevalent in a $\gamma \delta$ cell line and are absent in $\alpha \beta$ T cell and B cell lines. No evidence was found for the early waves of invariant rearrangement of TCR $\gamma \delta$ $\mathrm{T}$ cells seen for mouse and human (139). Notably, chicken-like sheep, cattle, and pigs-possess a high frequency of $\gamma \delta \mathrm{T}$ cells and also express a more complex repertoire of $\gamma$ and $\delta$ rearrangements. Thus, the $\operatorname{TCR} \gamma \delta$ characteristic described for the mouse and human may not be typical of vertebrates as a whole.

In the initial stages of the comparison of complex genetic systems, such as TCRs, similarities are likely to be recognized before differences are defined. With this bias in mind, the emerging consensus is that the broad-scale features of mammalian TCR genes can be found throughout the living representatives of the jawed vertebrates. This putative conservation of structure may result from an increased level of functional constraint that possibly represents an outcome of the more central role these receptors play in adaptive immunity. However, it is clear that this constraint does not extend to the TCR primary sequence, which exhibits extraordinary divergence relative to the Igs. It is likely that additional interpretations will emerge as TCR gene structures from an even wider variety of vertebrate taxa are elucidated and more extensive genomic studies are reported.

\section{T CELL MEMORY IN LOWER VERTEBRATES}

The recent description of TCR $\alpha, \beta, \gamma$, and $\delta$ genes in diverse vertebrate groups raises questions about conservation of $\mathrm{T}$ cell function throughout vertebrate phylogeny. $\mathrm{T}$ cell function typically has not been examined directly in 
nonmammalian species, but accelerated alloimmune reactions to secondary skin grafts have been used as a measure of T cell memory in many lower vertebrate species. Although alloantigens are probably poor indicators of the T cell response (140), these studies generally showed mildly accelerated responses to second-set grafts (141); however, the specificity of these results is unclear because of a lack of a third-party, unrelated donor control group. Given these caveats, two major types of allograft rejection patterns are observed. Mammals, avians, anuran amphibians, and teleost fish exhibit acute primary allograft rejection followed by accelerated secondary rejection, whereas urodele amphibians, reptiles, cartilaginous fish, and lamprey respond more slowly to primary allograft and show a gradual stepwise increase in reactivity to repeated allografts (141-143). The basis for the differences in allograft rejection patterns in these animal groups remains unknown, but it is clear that there is no simple phylogenetic pattern that implies stepwise acquisition of this cell-mediated function.

Strong evidence for cell-mediated immune memory in teleost fish is suggested by a study that used recombinant protein fragments from viral haemorrhagic septicemia rhabdovirus (VHSV) to stimulate trout leukocytes from survivors of VHSV infection or leukocytes from uninfected trout (144). Cellmediated immunity was detected by lymphocyte proliferation assays to detect increased sensitivity to activation. The persistence of sensitized, antigenspecific cells that proliferated in response to subsequent exposure to the primary stimulus is indicative of memory. Furthermore, the recombinant proteins were able to provide partial protection to trout after secondary challenge with the virus. The findings that chondrichthyan TCR and MHC genes are as diverse as their mammalian homologs essentially negates early speculation that restricted diversity in these molecules could relate to differences seen in allograft rejection in cartilaginous fish $(4,66,121)$. The recent definition of molecular markers for different lymphocyte populations $(22,30,42,121,145,146)$, along with progress in elasmobranch culture systems (147) (C Luer, C Walsh, personal communication), and a better understanding of the molecular mechanisms of mammalian memory should facilitate efforts to measure similar parameters in the cartilaginous fish.

\section{JAWLESS VERTEBRATE IMMUNITY}

The jawless vertebrates (Agnatha) are comprised of two extant groups (hagfishes and lampreys), which are the surviving remnants of a major evolutionary radiation and represent the most divergent extant vertebrate groups relative to the species that have been described in this review (Figure 1a). This divergence is reflected in significant anatomic, biochemical, and physiological differences relative to jawed vertebrates. The current consensus view places 
each of these two agnathan groups in lineages derived from separate common ancestors (polyphyly) with the jawed vertebrates (148), although evidence also exists for a single common ancestor (monophyly) (149). Although the mode of divergence of the hagfish and lamprey from common ancestor(s) with the higher vertebrates has important implications as to how to interpret immunity in these species, there is no doubt that study of them will offer a unique phylogenetic view into the immune system of the jawed vertebrates.

The agnathans lie across a phylogenetic boundary with regard to our current knowledge of vertebrate antigen binding receptors. Agnathans lack both a spleen and a thymus, which are present in all jawed vertebrate groups. Furthermore, the inducible immune response in lamprey is associated with a highly specific molecule(s) of a lectin-like character $(24,26)$. Although no fully systematic descriptions have been reported, a variety of approaches for identifying homologs of Ig, TCR, MHC I and II, and RAG genes have been unsuccessful with hagfish (Eptatretus stoutii) and lamprey (Petromyzon marinus), underscoring the major phylogenetic break in adaptive immune function between the jawed and jawless vertebrates (Figure 2). This failure could relate to the absence of such a receptor or to either qualitative or quantitative complications, e.g. low levels of expression, transient expression at different stages of development or expression in "atypical" tissues. Alternatively, antigen binding receptor gene homologs in these species may be present but have diverged appreciably. The successes in recovering Ig, MHC, and TCR in jawed vertebrates using PCRbased techniques has to some degree depended on the statistical advantages afforded by multiplicity of target motifs as well as inferred knowledge of their anatomic sites of expression. If the primary evolutionary event(s), presumably a transposition (5) (see below), which led to the rearrangement of segmental elements, was followed (under radically new selective pressure) by an expansion of gene number, then nonrearranging homologs in agnathans are possibly present in single- or low-copy number. Recent observations of extreme interspecies sequence divergence among orthologous novel immune-type receptor genes underscores how limited variation can impede the identification of homologous structures, even among different lineages of teleost fish (J Yoder, unpublished observation). A universal genetic strategy directed at the identification of the homologs of Ig and TCR in jawless vertebrates may not be feasible. Although it is plausible that homologs of relatively unconserved cell surface proteins may be difficult to identify in lamprey and hagfish, it should be possible to isolate highly conserved genes such as RAG (see below) from these species if homologs are present, i.e. failure to identify them is not likely to represent a technical artifact. It should be noted that the proportional difference in divergence time between the chondrichthyans and other jawed vertebrates ( $500 \mathrm{MYA})$ is not greatly different from that of the Agnathans and jawed vertebrates $(<600$ MYA), 
which suggests that more than mere clock-like divergence is responsible for the failure to isolate homologs in these species. Although presently based on entirely negative data, the findings from agnathan representatives are entirely consistent with the emergence of the jawed vertebrate adaptive immune system by a transposition event that took place after their divergence.

An important consideration of this real or perceived difference as regards antigen binding receptors in agnathans relates to the developmental biology of these species. Specifically, lampreys undergo metamorphosis from ammocoete larvae to the adult form. Characterization of gut-associated tissue (typhlosole) and the opisthonephros in the larval form of lampreys indicates the presence of lymphocytic/plasmocytic lineages. The typhlosole involutes prior to the first internal signs of metamorphosis and the opisthonephros involutes during metamorphosis. Metamorphosis is associated with a gain in lymphohemopoietic character of the protovertebral arch (supraneural body) (150; A Miracle, unpublished observation). It is possible that the adult (parasitic phase) of the lamprey life cycle is associated with a markedly different immune system than that seen in the larval form.

Even if jawless vertebrates lack readily recognizable homologs of MHC I, MHC II, TCR, and Ig, viewing the emergence of these molecules in the jawed vertebrates as a sudden event relative to the origins of jawed vertebrates needs to be reconsidered, given the significant time period separating these vertebrate radiations, a period of time that clearly was of sufficient length to allow for drastic morphological change. Finally, it remains possible that species that diversified prior to the jawless vertebrates, e.g. protochordates, could retain homologs of antigen binding receptor genes that are more related to their higher vertebrate counterparts.

\section{GENES AFFECTING DIFFERENTIATION OF LYMPHOCYTES AND THE GENERATION OF IMMUNOLOGICAL DIVERSITY}

The commitment of specific hematopoietic lineages to the expression of specific antigen binding receptor genes is significant both in terms of defining the anatomical sites of synthesis of immune receptors and in the potential for identifying related lineages in species that diverged prior to the jawed vertebrates. $\mathrm{T}, \mathrm{B}$, and NK cell lineage differentiation is dependent on the expression of the genes related to the Ikaros transcription factor. The Ikaros gene undergoes differential processing to produce a variety of different zinc-finger DNA binding transcription factors $(151,152)$. Ikaros is expressed in chickens from day 2 onward, prior to the transfer of the first precursor cells to the lymphoid primordia, thymus and bursa (153), as well as in Xenopus (154). In trout, Ikaros, 
a single copy gene, is expressed in six different spliced isoforms also found in mammals and in two novel forms (154). The expression of Ikaros in trout and Xenopus is primarily lymphoid and occurs early in development (154). Unique differentially processed forms of Ikaros as well as related family members [Helios, Aiolos (152)] have been identified in skate (R Haire, A Miracle, unpublished observation). Regardless of the function of these genes, they are potentially valuable markers of immune cells in divergent species.

Identification and characterization of various other transcription factors, which in general are more conserved than cell surface markers, in different vertebrate species could prove informative in understanding similarities and differences in B cell development and function. Specifically, studies in higher vertebrates have identified transcription factors that are critical to both the initial formation of germinal centers and the differentiation pathways toward either the plasma cell or the memory cell phenotype, e.g. Blimp-1 and BSAP (Pax-5) promote plasma cell or germinal center formation, respectively. These factors also influence germinal center B cells, promoting either plasma cell or memory cell formation following affinity maturation (155).

The evolutionary stability of $\operatorname{RSSs}(5,32,156,157)$ and the requisite involvement of RAG1 and 2 in Ig and TCR gene rearrangement represent other potential approaches for examining the immune systems of species found below the phylogenetic level of the jawed vertebrates. Specifically, RAG1 has been identified in mammals, avians, amphibians, ray-finned fish, and cartilaginous fish (5). Shared regions of RAG1 in sandbar shark and zebrafish (Danio rerio) as well as in other higher vertebrates reveal high degrees of amino acid identity $(158,159)$. RAG2 is somewhat less conserved phylogenetically than is RAG1 (160), but RAG1 and RAG2 are found in the same relative close proximity in lower vertebrates as in mammals (161). In mammals, avians, and amphibians, RAG1 and 2 are encoded by single exons, in opposite transcriptional orientation. However, in zebrafish the coding region of RAG1 is interrupted by two introns (162), and in trout, the coding region is interrupted by a single intron (163). These intronic relationships need to be considered in the design of strategies to identify RAG homologs in other species. The conserved close physical linkage of RAG1 and 2 in trout, zebrafish, and Xenopus (160-162) and higher vertebrates suggests that the identification of a homolog of one of these genes would lead to the isolation of the second. The observations of RAG2 gene expression in oocytes in Xenopus (160) and early in development in trout (161) are of strategic significance in terms of potential PCR template sources in other species. Although identification of RAG in a jawless vertebrate species would be of great significance, there is a distinct possibility that its presence in jawed vertebrates is the result of a horizontal gene transfer event and thus a homolog would not necessarily be present in jawless vertebrates or protochordates. 
TdT functions in generating junctional diversity, which has been documented in species as phylogenetically distant from mammals as the cartilaginous fish $(18,121)$. TdT expression has been characterized in species as phylogenetically distant from man as amphibians (164) and ray-finned fish (165). Bruton's tyrosine kinase (BTK), a nonreceptor protein tyrosine kinase, is essential for normal B lymphocyte development but is not expressed in T cells; a Btk homolog has been identified in skate (145). CD45, a TM tyrosine phosphatase that is required for antigen-induced signal transduction in mammalian lymphocytes, is expressed in horned shark (146). Investigations into the concordance of expression of antigen receptors, lymphocyte-specific enzymes such as RAG and TdT, transcription factors, and other genes implicated in lymphoid development have the potential for providing additional insight into the sites of hematopoiesis and the molecular events governing lymphocyte development and activation in diverse vertebrate groups. However, it also must be recognized that the transcription factors are often utilized in a variety of unrelated systems.

\section{ORIGINS OF ANTIGEN BINDING RECEPTORS}

The phylogenetic approach that has been at the core of this review has provided a wealth of information regarding the evolution of rearranging gene families; however, it offers little in the way of defining the early evolutionary origins of antigen binding receptors, other than to constrain the time of origin and diversification of all six rearranging gene classes (TCR $\alpha, \beta, \gamma, \delta$, and Ig lightchain and Ig heavy-chain genes) to a period prior to the divergence of the cartilaginous and ray-finned fishes, 460-550 MYA. Inferring characteristics of primitive receptor forms through phylogenetic analysis of existing rearranging genes is complicated by the highly derived nature of the antigen binding receptors. Nevertheless, some relationships are evident, e.g. $\operatorname{TCR} \beta$ is more related to $\operatorname{TCR} \gamma$, and TCR $\alpha$ is more related to $\operatorname{TCR} \delta$ at the sequence level than either is between these two groups. The D regions appear to have evolved or were lost more than once during the evolution of TCRs. Additional sources of information may prove useful in cases where the limited data from primary sequence is inadequate, e.g. the syntenic organization of genes encoded in the chromosomal vicinity of the rearranging receptors could be useful in relating them to one another. Also, as more information regarding the coreceptors and transcriptional regulation of antigen binding receptor genes becomes available, a more complete picture of the early evolutionary history of these proteins may emerge from affinities in regulation and function.

Nonrearranging genes that descended from the prerearranging ancestral antigen binding receptor may still exist in invertebrates and protochordates as well 
as in jawed vertebrates. A number of potential nonrearranging ancestral-like candidate genes are known that contain TCR/Ig-like $\mathrm{V}$ regions, including $\mathrm{CD} 8 \beta$ and VpreB. Notably, both of these genes are encoded very near rearranging genes in mice and have functions that are consistent with an ancient association with these antigen recognition systems. A particularly interesting set of nonrearranging genes termed novel immune-type receptors (NITR) was isolated initially from the Southern pufferfish using a V region degenerate PCR strategy that was employed to isolate TCR genes (122). The prototypic NITR gene (Sn193) consists of a V domain and a C2 domain, as well as TM and cytoplasmic (Cyt) regions. The $\mathrm{V}$ region domain exhibits remarkable similarity to TCR and Ig V regions beyond that which is displayed by other nonrearranging $\mathrm{V}$ region-containing Ig domain proteins; a J-like region is located $3^{\prime}$ of V. P1 artificial chromosomes were isolated using Sn193 as well as several related genes as probes, and a large number of related genes were identified in tandem linkage over a $>100-\mathrm{kb}$ region. The NITR genes exhibit extensive TCR-like $\mathrm{V}$ region diversification, and the majority characterized thus far contain ITIM motifs in their cytoplasmic regions (S Strong, G Mueller, R Litman, N Hawke, R Haire, A Miracle, J Rast, C Amemiya, G Litman, unpublished observation). NITR genes may represent a link between conventional V-type recognition, innate function, and signaling pathways known to function in recognition molecules such as certain NK receptors that are members of a newly defined superfamily of ITIM-containing genes, the inhibitory receptor superfamily (166).

A number of additional $\mathrm{V}$ region domain-containing cell surface molecules, including $\mathrm{CD} 8 \beta$, OX-2, CTX $(167)$, and ChT1 $(168,169)$, have varying degrees of Ig/TCR-like character. The two Xenopus CTX genes contain a V and $\mathrm{C} 2 \mathrm{Ig}$ domain, both of which are split by introns. A J-like region is present, including a glycine bulge motif $\mathrm{C}$ terminal to the $\mathrm{V}$ region $(167,170)$. One of the Xenopus genes is encoded within the MHC region. The chicken ChT1 protein has a domain and intron/exon structure similar to that of CTX but is not linked to the chicken MHC (168; K Katevuo, personal communication). Both these genes are expressed in thymic $\mathrm{T}$ cells and possibly derive from an early TCR ancestral molecule. Recently, mammalian homologs of CTX and ChT1 were identified; however, these genes are not expressed in thymus (169). It is of great interest to researchers to determine if CTX/ChT1 genes can be detected in ray-finned and/or cartilaginous fish. All vertebrate rearranging receptors, along with class I and II MHC proteins, contain Ig C1-type domains. If the MHC genes are primitively nonrearranging, then the initial hypothesized transposition event that led to rearranging receptors is likely to have interrupted a V-C1-TM-Cyt-type molecule. The V-C2-TM-Cyt general structure, found in a variety of vertebrate genes along with the pufferfish NITR, may reflect the antigen receptor predecessor of $\mathrm{IgC} 1$-containing, nonrearranging receptor. 
Further clarification of the origins and interrelationships of these putative receptors will come through phylogenetic comparisons between rearranging and nonrearranging antigen binding receptors found in jawed vertebrates. Such analyses will also be significant in terms of designing strategies for identification of related systems in agnathans, lower chordates, hemichordates, and echinoderms. The recent discovery that RAG1 and RAG2 proteins together constitute a transposase, capable of excising a piece of DNA containing recombination signals from a donor site and inserting into a target DNA molecule, has enormous bearing on mechanisms whereby nonrearranging receptors diverged into the rearranging antigen binding receptor genes (171).

\section{CONCLUSIONS}

The origins of Ig and TCR, as inferred from studies of contemporary species, can be traced to a distant period in the phylogenetic development of the jawed vertebrates. Available information suggests that the character of TCR genes has been conserved throughout vertebrates, whereas Ig genes have undergone a series of changes, of which some segregate to major phylogenetic radiations and others are specific to less inclusive taxonomic groups. A series of genetic divergences can be recognized throughout the jawed vertebrates that reflect a process of continued evolutionary variation of potential mechanisms of diversification. One such step separates species in which heavy- and light-chain genes are encoded at a single locus from those in which large numbers of individual loci are present. In the latter case, which is found in all cartilaginous fish (e.g. sharks), certain gene clusters are joined in the germline, whereas others hypermutate extensively. It is likely that the regulation of expression of single and multicluster Ig gene loci differs markedly. Other variations in Ig structure and regulation are seen throughout the radiations of ray- and fleshy-finned fish as well as the tetrapods, including the following: the use of alternative processing mechanisms, partial precommitment of rearranging segment elements, nonassociation of light chains with heavy chains, and the use of both gene conversion and antigen-independent somatic hyperconversion as a primary basis for varying receptor structure. Some of the exceptional phenomena typically are associated with specialized lymphocyte compartments and corresponding unique microenvironments. The basis for the remarkable plasticity in form and function of both Ig and TCR is not understood. Studies to date in jawless vertebrates have failed to provide evidence for antigen binding receptors resembling those found in jawed vertebrates, nor have homologous structures been identified in more phylogenetically distant forms. It remains open to question whether other heretofore unrecognized genetic systems related to Ig and TCR also function in antigen binding. Several nonrearranging genes that have been characterized 
in jawed vertebrates exhibit varying levels of sequence identity with the rearranging antigen binding receptors and could represent either modern forms of progenitor genes or derived products of Ig and TCR loci. Such gene products, which would function in an innate capacity, could offer new information as to how the highly complex diversified process of antigen recognition has evolved.

\section{ACKNOWLEDGMENTS}

We would like to thank Chris Amemiya, Louis Du Pasquier, Martin Flajnik, Robert Haire, Noel Hawke, Kasia Katevuo, Carl Luer, Ann Miracle, Tatsuya Ota, David Schatz, Scott Strong, Gregory Warr, and Jeffrey Yoder for sharing their unpublished findings and their valuable comments. We would also like to thank Michael Sexton for his assistance with the figures and Barbara Pryor for editorial assistance. This work was supported by Grant R37 AI23338 to GWL from the National Institutes of Health. MKA is supported by the Stowers Institute for Medical Research. JPR is supported by an NRSA Grant GM 18478.

Visit the Annual Reviews home page at http://www.AnnualReviews.org

Literature Cited

1. Williams AF, Barclay AN. 1988. The immunoglobulin superfamily-domains for cell surface recognition. Annu. Rev. Immunol. 6:381-405

2. Medzhitov R, Janeway CA. 1997. Innate immunity: impact on the adaptive immune response. Curr. Opin. Immunol. 9:4-9

3. Medzhitov R, Preston-Hurlburt P, Janeway CA. 1997. A human homologue of the Drosophila Toll protein signals activation of adaptive immunity. Nature 388:394-97

4. Bartl S, Baltimore D, Weissman IL. 1994. Molecular evolution of the vertebrate immune system. Proc. Natl. Acad. Sci. USA 91:10769-70

5. Thompson CB. 1995. New insights into $\mathrm{V}(\mathrm{D}) \mathrm{J}$ recombination and its role in the evolution of the immune system. Immunity 3:531-39

6. Litman GW, Rast JP. 1996. The organization and structure of immunoglobulin and T-cell receptor genes in the most phylogenetically distant jawed vertebrates: evolutionary implications. Res. Immunol. 147:226-33

7. Kokubu F, Litman R, Shamblott MJ, Hinds K, Litman GW. 1988. Diverse organization of immunoglobulin $\mathrm{V}_{\mathrm{H}}$ gene loci in a primitive vertebrate. $E M B O \mathrm{~J}$. 7:3413-22

8. Anderson MK, Shamblott MJ, Litman RT, Litman GW. 1995. The generation of immunoglobulin light chain gene diversity in Raja erinacea is not associated with somatic rearrangement, an exception to a central paradigm of B cell immunity. $J$. Exp. Med. 181:109-19

9. Zheng B, Xue W, Kelsoe G. 1994. Locusspecific somatic hypermutation in germinal centre T cells. Nature 372:55659

10. Wagner SD, Neuberger MS. 1996. Somatic hypermutation of immunoglobulin genes. Annu. Rev. Immunol. 14:441-57

11. Du Pasquier L, Wilson M, Greenberg AS, Flajnik MF. 1998. Somatic mutation in ectothermic vertebrates: musings on selection and origins. Curr. Top. Microbiol. Immunol. 229:199-216

12. Hinds KR, Litman GW. 1986. Major reorganization of immunoglobulin $\mathrm{V}_{\mathrm{H}}$ segmental elements during vertebrate evolution. Nature 320:546-49

13. Harding FA, Cohen N, Litman GW. 1990. Immunoglobulin heavy chain gene organization and complexity in the skate, Raja erinacea. Nucleic Acids Res. 18:1015-20

14. Rast JP, Amemiya CT, Litman RT, Strong 
SJ, Litman GW. 1998. Distinct patterns of $\mathrm{IgH}$ structure and organization in a divergent lineage of chondrichthyan fishes. Immunogenetics 47:234-45

15. Carroll RL. 1988. Vertebrate Paleontology and Evolution. New York: Freeman

16. Kumar S, Hedges SB. 1998. A molecular timescale for vertebrate evolution. Nature 392:917-20

17. Litman GW, Berger L, Murphy K, Litman R, Hinds KR, Erickson BW. 1985. Immunoglobulin $\mathrm{V}_{\mathrm{H}}$ gene structure and diversity in Heterodontus, a phylogenetically primitive shark. Proc. Natl. Acad. Sci. USA 82:2082-86

18. Hinds-Frey KR, Nishikata H, Litman RT, Litman GW. 1993. Somatic variation precedes extensive diversification of germline sequences and combinatorial joining in the evolution of immunoglobulin heavy chain diversity. J. Exp. Med. 178:825-34

19. Kokubu F, Hinds K, Litman R, Shamblott MJ, Litman GW. 1988. Complete structure and organization of immunoglobulin heavy chain constant region genes in a phylogenetically primitive vertebrate. EMBO J. 7:1979-88

20. Kokubu F, Hinds K, Litman R, Shamblott MJ, Litman GW. 1987. Extensive families of constant region genes in a phylogenetically primitive vertebrate indicate an additional level of immunoglobulin complexity. Proc. Natl. Acad. Sci. USA 84:5868-72

21. Anderson M, Amemiya C, Luer C, Litman R, Rast J, Niimura Y, Litman G. 1994. Complete genomic sequence and patterns of transcription of a member of an unusual family of closely related, chromosomally dispersed immunoglobulin gene clusters in Raja. Int. Immunol. 6:1661-70

22. Greenberg AS, Avila D, Hughes M, Hughes A, McKinney EC, Flajnik MF. 1995. A new antigen receptor gene family that undergoes rearrangement and extensive somatic diversification in sharks. Nature 374:168-73

23. Anderson MK, Strong SJ, Litman RT, Luer CA, Amemiya CT, Rast JP, Litman GW. 1998. A long form of the IgX gene in the skate exhibits a striking resemblance to the novel IgW and IgNARC genes in the shark. Immunogenetics 47: In press

24. Rast JP, Anderson MK, Litman GW. 1995. The structure and organization of immunoglobulin genes in lower vertebrates. See Ref. ?, pp. 315-41

25. Ota T, Nei M. 1994. Divergent evolution and evolution by the birth-and-death process in the immunoglobulin $\mathrm{V}_{\mathrm{H}}$ gene family. Mol. Biol. Evol. 11:469-82

26. Litman GW, Rast JP, Shamblott MJ, Haire RN, Hulst M, Roess W, Litman RT, Hinds-Frey KR, Zilch A, Amemiya CT. 1993. Phylogenetic diversification of immunoglobulin genes and the antibody repertoire. Mol. Biol. Evol. 10:60-72

27. Roux KH, Greenberg AS, Greene L, Strelets L, Avila D, McKinney EC, Flajnik MF. 1998. Molecular convergence of the nurse shark (new) antigen receptor (NAR) and unusual mammalian immunoglobulins. PNAC 95:11,804-9

28. Hamers-Casterman $\mathrm{C}$, Atarhouch $\mathrm{T}$, Muyldermans S, Robinson G, Hamers C, Songa EB, Bendahman N, Hamers R. 1993. Naturally occurring antibodies devoid of light chains. Nature 363:446-48

29. Desmyter A, Transue TR, Ghahroudi MA, Thi M-HD, Poortmans F, Hamers R, Muyldermans S, Wyns L. 1996. Crystal structure of a camel single-domain $\mathrm{V}_{\mathrm{H}}$ antibody fragment in complex with lysozyme. Nat. Struct. Biol. 3:803-11

30. Harding FA, Amemiya CT, Litman RT, Cohen N, Litman GW. 1990. Two distinct immunoglobulin heavy chain isotypes in a primitive, cartilaginous fish, Raja erinacea. Nucleic Acids Res. 18:6369-76

31. Chess A, Simon I, Cedar H, Axel R. 1994. Allelic inactivation regulates olfactory receptor gene expression. Cell 78:82334

32. Litman GW, Anderson MK, Rast JP, Amemiya CT. 1996. Organization and mechanism of rearrangement of immunoglobulin genes in lower vertebrates. In Wier's Handbook of Experimental Immunology, Immunochemistry and Molecular Biology, ed. LA Herzenberg, DM Weir, L Herzenberg, C Blackwell, 1:114. Boston: Blackwell Sci. 5th ed.

33. Berstein RM, Schluter SF, Shen S, Marchalonis JJ. 1996. A new high molecular weight immunoglobulin class from the carcharhine shark: implications for the properties of the primordial immunoglobulin. Proc. Natl. Acad. Sci. USA 93:328993

34. Greenberg AS, Hughes AL, Guo J, Avila D, McKinney EC, Flajnik MF. 1996. A novel "chimeric" antibody class in cartilaginous fish: IgM may not be the primordial immunoglobulin. Eur. J. Immunol. 26:1123-29

35. Diaz M, Greenberg AS, Flajnik MF. 1998. Somatic hypermutation of the new antigen receptor gene (NAR) in the nurse shark does not generate the repertoire: possible role in antigen-driven reactions 
in the absence of germinal centers. PNAS. In press

36. Shamblott MJ, Litman GW. 1989. Complete nucleotide sequence of primitive vertebrate immunoglobulin light chain genes. Proc. Natl. Acad. Sci. USA 86: 4684-88

37. Shamblott MJ, Litman GW. 1989. Genomic organization and sequences of immunoglobulin light chain genes in a primitive vertebrate suggest coevolution of immunoglobulin gene organization. EMBO J. 8:3733-39

38. Litman GW, Haire RN, Hinds KR, Amemiya CT, Rast JP, Hulst MA. 1992. Evolutionary development of the B-cell repertoire. Ann. NY Acad. Sci. 651:36068

39. Hohman VS, Schluter SF, Marchalonis JJ. 1992. Complete sequence of a cDNA clone specifying sandbar shark immunoglobulin light chain: gene organization and implications for the evolution of light chains. Proc. Natl. Acad. Sci. USA 89:276-80

40. Hohman VS, Schuchman DB, Schluter SF, Marchalonis JJ. 1993. Genomic clone for the sandbar shark lambda light chain: generation of diversity in the absence of gene rearrangement. Proc. Natl. Acad. Sci. USA 90:9882-86

41. Hohman VS, Schluter SF, Marchalonis JJ. 1995. Diversity of Ig light chain clusters in the sandbar shark (Carcharhinus plumbeus). J. Immunol. 155:3922-28

42. Rast JP, Anderson MK, Ota T, Litman RT, Margittai M, Shamblott MJ, Litman GW. 1994. Immunoglobulin light chain class multiplicity and alternative organizational forms in early vertebrate phylogeny. Immunogenetics 40:83-99

43. Greenberg AS, Steiner L, Kasahara M, Flajnik MF. 1993. Isolation of a shark immunoglobulin light chain cDNA clone encoding a protein resembling mammalian type kappa light chains: implications for the evolution of light chains. Proc. Natl. Acad. Sci. USA 90:10603-7

44. Sitnikova T, Nei M. 1998. Evolution of immunoglobulin kappa chain variable region genes in vertebrates. Mol. Biol. Evol. 15:50-60

45. Amemiya CT, Litman GW. 1990. The complete nucleotide sequence of an immunoglobulin heavy chain gene and analysis of immunoglobulin gene organization in a primitive teleost species. Proc. Natl. Acad. Sci. USA 87:811-15

46. Ventura-Holman T, Jones JC, Ghaffari SH, Lobb CJ. 1994. Structure and genomic organization of $\mathrm{VH}$ gene segments in the channel catfish: members of different $\mathrm{V}_{\mathrm{H}}$ gene families are interspersed and closely linked. Mol. Immunol. 31:82332

47. Ghaffari SH, Lobb CJ. 1989. Cloning and sequence analysis of channel catfish heavy chain cDNA indicate phylogenetic diversity within the IgM immunoglobulin family. J. Immunol. 142:1356-65

48. Wilson MR, Marcuz A, van Ginkel F, Miller NW, Clem LW, Middleton D, Warr GW. 1990. The immunoglobulin M heavy chain constant region gene of the channel catfish, Ictalurus punctatus: an unusual mRNA splice pattern produces the membrane form of the molecule. Nucleic Acids Res. 18:5227-33

49. Lee MA, Bengten E, Daggfeldt A, Rytting A-S, Pilström L. 1993. Characterisation of rainbow trout cDNAs encoding a secreted and membrane-bound Ig heavy chain and the genomic intron upstream of the first constant region. Mol. Immunol. 30:641-48

50. Warr GW, Miller NW, Clem LW, Wilson MR. 1992. Alternative splicing pathways of the immunoglobulin heavy chain transcript of a teleost fish, Ictalurus punctatus. Immunogenetics 35:253-56

51. Wilson MR, Ross DA, Miller NW, Clem LW, Middleton DL, Warr GW. 1995. Alternative pre-mRNA processing pathways in the production of membrane IgM heavy chains in holostean fish. Dev. Comp. Immunol. 19:65-77

52. Rycyzyn MA, Wilson MR, Warr GW, Clem LW, Miller NW. 1996. Membrane immunoglobulin-associated molecules on channel catfish B lymphocytes. Dev. Comp. Immunol. 20:341-51

53. Magor BG, Wilson MR, Miller NW, Clem LW, Middleton DL, Warr GW. 1994. An Ig heavy chain enhancer of the channel catfish Ictalurus punctatus: evolutionary conservation of function but not structure. J. Immunol. 153:5556-63

54. Hayman JR, Ghaffari SH, Lobb CJ. 1993. Heavy chain joining region segments of the channel catfish. Genomic organization and phylogenetic implications. J. Immunol. 151:3587-96

55. Roman T, Charlemagne J. 1994. The immunoglobulin repertoire of the rainbow trout (Oncorhynchus mykiss): definition of nine Igh- $\mathrm{V}$ families. Immunogenetics $40: 210-16$

56. Roman T, Andersson E, Bengten E, Hansen J, Kaattari S, Pilstrom L, Charlemagne J, Matsunaga T. 1996. Unified nomenclature of $\mathrm{Ig} \mathrm{V}_{\mathrm{H}}$ genes in rainbow trout (Oncorhynchus mykiss): definition 
of eleven $\mathrm{V}_{\mathrm{H}}$ families. Immunogenetics 43:325-26

57. Roman T, de Guerra A, Charlemagne J. 1995. Evolution of specific antigen recognition: size reduction and restricted length distribution of the $\mathrm{CDRH} 3$ regions in the rainbow trout. Eur. J. Immunol. 25:269-73

58. Wilson M, Bengtén E, Miller NW, Clem LW, Du Pasquier L, Warr GW. 1997. A novel chimeric Ig heavy chain from a teleost fish shares similarities to IgD. Proc. Natl. Acad. Sci. USA 94:459397

59. Lundqvist M, Bengtén E, Strömberg S, Pilström L. 1996. Ig light chain gene in the Siberian sturgeon (Acipenser baeri): implications for the evolution of the immune system. J. Immunol. 157:203138

60. Daggfeldt A, Bengten E, Pilström L. 1993. A cluster type organization of the loci of the immunoglobulin light chain in Atlantic cod (Gadus morhua L.) and rainbow trout (Oncorhynchus mykiss Walbaum) indicated by nucleotide sequences of cDNAs and hybridization analysis. Immunogenetics 38:199-209

61. Ghaffari SH, Lobb CJ. 1993. Structure and genomic organization of immunoglobulin light chain in the channel catfish. An unusual genomic organizational pattern of segmental genes. J. Immunol. 151:6900-12

62. Partula S, Schwager J, Timmusk S, Pilstrom L, Charlemagne J. 1996. A second immunoglobulin light chain isotype in the rainbow trout. Immunogenetics 45:44-51

63. Ghaffari SH, Lobb CJ. 1997. Structure and genomic organization of a second class of immunoglobulin light chain genes in the channel catfish. J. Immunol. 159:250-58

64. Amemiya CT, Ohta Y, Litman RT, Rast JP, Haire RN, Litman GW. 1993. V ${ }_{\mathrm{H}}$ gene organization in a relict species, the coelacanth Latimeria chalumnae: evolutionary implications. Proc. Natl. Acad. Sci. USA 90:6661-65

65. Ota T, Rast JP, Litman GW, Amemiya CT. 1997. Lungfish immunoglobulins and their evolutionary implications. Dev. Comp. Immunol. 21:159 (Abstr.)

66. Du Pasquier L, Flajnik M. 1998. Origin and evolution of the vertebrate immune system. In Fundamental Immunology, ed. WE Paul. New York: Raven. 4th ed. In press

67. Mussmann R, Wilson M, Marcuz A, Courtet M, Du Pasquier L. 1996. Membrane exon sequences of the three Xeno- pus Ig classes explain the evolutionary origin of mammalian isotypes. Eur. J. Immunol. 26:409-14

68. Mussmann R, Du Pasquier L, Hsu E. 1996. Is Xenopus IgX an analog of IgA? Eur. J. Immunol. 26:2823-30

69. Mussmann R, Courtet M, Schwager J, Du Pasquier L. 1997. Microsites for immunoglobulin switch recombination breakpoints from Xenopus to mammals. Eur. J. Immunol. 27:2610-19

70. Schwager J, Burckert N, Courtet M, Du Pasquier L. 1989. Genetic basis of the antibody repertoire in Xenopus: analysis of the $\mathrm{V}_{\mathrm{H}}$ diversity. EMBO J. 8:2989-3001

71. Hsu E, Schwager J, Alt FW. 1989. Evolution of immunoglobulin genes: $\mathrm{V}_{\mathrm{H}}$ families in the amphibian Xenopus. Proc. Natl. Acad. Sci. USA 86:8010-14

72. Haire RN, Amemiya CT, Suzuki D, Litman GW. 1990. Eleven distinct $\mathrm{V}_{\mathrm{H}}$ gene families and additional patterns of sequence variation suggest a high degree of immunoglobulin gene complexity in a lower vertebrate, Xenopus laevis. J. Exp. Med. 171:1721-37

73. Haire RN, Ohta Y, Litman RT, Amemiya CT, Litman GW. 1991. The genomic organization of immunoglobulin $\mathrm{V}_{\mathrm{H}}$ genes in Xenopus laevis shows evidence for interspersion of families. Nucleic Acids Res. 19:3061-66

74. Schwager J, Burckert N, Courtet M, Du Pasquier L. 1991. The ontogeny of diversification at the immunoglobulin heavy chain locus in Xenopus. EMBO J. 10:2461-70

75. Fellah JS, Kerfourn F, Wiles MV, Schwager J, Charlemagne J. 1993. Phylogeny of immunoglobulin heavy chain isotypes: structure of the constant region of $\mathrm{Am}$ bystoma mexicanum upsilon chain deduced from cDNA sequence. Immunogenetics 38:311-17

76. Fellah JS, Jacques C, Charlemagne J. 1994. Characterization of immunoglobulin heavy chain variable regions in the Mexican axolotl. Immunogenetics 39:201-6

77. Golub R, Fellah JS, Charlemagne J. 1997. Structure and diversity of the heavy chain $V D J$ junctions in the developing Mexican axolotl. Immunogenetics 46:402-9

78. Patel HM, Hsu E. 1997. Abbreviated junctional sequences impoverish antibody diversity in urodele amphibians. J. Immunol. 159:3391-99

79. Schwager J, Burckert N, Schwager M, Wilson M. 1991. Evolution of immunoglobulin light chain genes: analysis of Xenopus IgL isotypes and their con- 
tribution to antibody diversity. $E M B O \mathrm{~J}$. 10:505-11

80. Zezza DJ, Stewart SE, Steiner LA. 1992. Genes encoding Xenopus laevis Ig L chains: implications for the evolution of kappa and lambda chains. J. Immunol. 149:3968-77

81. Haire RN, Ota T, Rast JP, Litman RT, Chan FY, Zon LI, Litman GW. 1996. A third Ig light chain gene isotype in Xenopus laevis consists of six distinct $\mathrm{V}_{\mathrm{L}}$ families and is related to mammalian lambda genes. J. Immunol. 157:1544-50

82. Litman GW, Murphy K, Berger L, Litman RT, Hinds KR, Erickson BW. 1985. Complete nucleotide sequences of three $\mathrm{V}_{\mathrm{H}}$ genes in Caiman, a phylogenetically ancient reptile: evolutionary diversification in coding segments and variation in the structure and organization of recombination elements. Proc. Natl. Acad. Sci. USA 82:844-48

83. Turchin A, Hsu E. 1996. The generation of antibody diversity in the turtle. $\mathrm{J}$. Immunol. 156:3797-805

84. Reynaud C-A, Bertocci B, Dahan A, Weill J-C. 1994. Formation of the chicken Bcell repertoire: ontogenesis, regulation of Ig gene rearrangement, and diversification by gene conversion. Adv. Immunol. 57:353-78

85. Vainio O, Imhof BA. 1995. The immunology and developmental biology of the chicken. Immunol. Today 16:365-70

86. Weill J-C, Reynaud C-A. 1995. Generation of diversity by post-rearrangement diversification mechanisms: the chicken and the sheep antibody repertoires. See Ref. ?, pp. 267-88

87. Magor KE, Warr GW, Bando Y, Middleton DL, Higgins DA. 1998. Secretory immune system of the duck (Anas platyrhynchos). Identification and expression of the genes encoding IgA and IgM heavy chains. Eur. J. Immunol. 28:1063-68

88. Magor KE, Warr GW, Middleton D, Wilson MR, Higgins DA. 1992. Structural relationship between the two IgY of the duck, Anas platyrhynchos: molecular genetic evidence. J. Immunol. 149:262733

89. Magor KE, Higgins DA, Middleton DL, Warr GW. 1994. One gene encodes the heavy chains for three different forms of IgY in the duck. J. Immunol. 153:5549-55

90. Warr GW, Magor KE, Higgins DA. 1995. IgY: clues to the origins of modern antibodies. Immunol. Today 16:392-98

91. Reynaud C-A, Dahan A, Anquez V, Weill J-C. 1989. Somatic hyperconversion diversifies the single $\mathrm{V}_{\mathrm{H}}$ gene of the chicken with a high incidence in the D region. Cell 59:171-83

92. Reynaud C-A, Anquez V, Weill J-C. 1991. The chicken D locus and its contribution to the immunoglobulin heavy chain repertoire. Eur. J. Immunol. 21:2661-70

93. Knight KL. 1992. Restricted $\mathrm{V}_{\mathrm{H}}$ gene usage and generation of antibody diversity in rabbit. Annu. Rev. Immunol. 10:593616

94. Parng CL, Hansal S, Goldsby RA, Osborne BA. 1996. Gene conversion contributes to Ig light chain diversity in cattle. J. Immunol. 157:5478-86

95. Meyer A, Parng CL, Hansal SA, Osborne BA, Goldsby RA. 1997. Immunoglobulin gene diversification in cattle. Int. Rev. Immunol. 15:165-83

96. Sun J, Butler JE. 1996. Molecular characterization of VDJ transcripts from a newborn piglet. Immunology 88:331-39

97. Thompson CB, Nieman PE. 1987. Somatic diversification of the chicken immunoglobulin light chain gene is limited to the rearranged variable gene segment. Cell 48:369-78

98. Reynaud C-A, Anquez V, Grimal H, Weill J-C. 1987. A hyperconversion mechanism generates the chicken light chain preimmune repertoire. Cell 48:379-88

99. Kondo T, Arakawa H, Kitao H, Hirota Y, Yamagishi H. 1993. Signal joint of immunoglobulin $\mathrm{V} \lambda 1-\mathrm{J} \lambda$ and novel joints of chimeric $\mathrm{V}$ pseudogenes on extrachromosomal circular DNA from chicken bursa. Eur. J. Immunol. 23:245-49

100. McCormack WT, Carlson LM, Tjoelker LW, Thompson CB. 1989. Evolutionary comparison of the avian IgL locus: combinatorial diversity plays a role in the generation of the antibody repertoire in some avian species. Int. Immunol. 1:332-41

101. McCormack WT, Thompson CB. 1990. Chicken IgL variable region gene conversions display pseudogene donor preference and $5^{\prime}$ to $3^{\prime}$ polarity. Genes Dev. 4:548-58

102. McCormack WT, Tjoelker LW, Carlson LM, Petryniak B, Barth CF, Humphries EH, Thompson CB. 1989. Chicken IgL gene rearrangement involves deletion of a circular episome and addition of single nonrandom nucleotides to both coding segments. Cell 56:785-91

103. McCormack WT, Hurley EA, Thompson CB. 1993. Germ line maintenance of the pseudogene donor pool for somatic immunoglobulin gene conversion in chickens. Mol. Cell. Biol. 13:821-30

104. Nahm MH, Kroese FG, Hoffmann JW. 1992. The evolution of immune mem- 
ory and germinal centers. Immunol. Today 13:438-41

105. Wilson M, Hsu E, Marcuz A, Courtet M, Du Pasquier L, Steinberg C. 1992. What limits affinity maturation of antibodies in Xenopus - the rate of somatic mutation or the ability to select mutants? EMBO J. 11:4337-47

106. Reynaud C-A, Garcia C, Hein WR, Weill J-C. 1995. Hypermutation generating the sheep immunoglobulin repertoire is an antigen-independent process. Cell 80:115-25

107. Jacob J, Kelsoe G, Rajewsky K, Weiss U. 1991. Intraclonal generation of antibody mutants in germinal centres. Nature 354:389-92

108. Mäkelä O, Litman GW. 1980. Lack of heterogeneity in anti-hapten antibodies of a phylogenetically primitive shark. Nature 287:639-40

109. Litman GW, Erickson BW, Lederman L, Mäkelä O. 1982. Antibody response in Heterodontus. Mol. Cell. Biochem. 45: 49-57

110. van Muiswinkel WB, Wiegertjes GF. 1997. Immune responses after injection vaccination of fish. Dev. Biol. Stand. 90: 55-57

111. Du Pasquier L. 1993. Phylogeny of B cell development. Curr. Opin. Immunol. 5:185-93

112. Ruben LN. 1983. IgM memory: long lived hapten-specific memory in the newt, Notophthalmus viridescens. Immunology 48:385-92

113. Farber DL. 1998. Differential TCR signaling and the generation of memory $\mathrm{T}$ cells. J. Immunol. 160:535-39

114. Decker DJ, Linton P-J, Zaharevitz S, Biery M, Gingeras TR, Klinman NR. 1995. Defining subsets of naive and memory B cells based on the ability of their progeny to somatically mutate in vitro. Immunity 2:195-203

115. Tjoelker LW, Carlson LM, Lee K, Lahti J, McCormack WT, Leiden JM, Chen CLH, Cooper MD, Thompson CB. 1990. Evolutionary conservation of antigen recognition: the chicken T-cell receptor $\beta$ chain. Proc. Natl. Acad. Sci. USA 87: 7856-60

116. Murphy PM. 1993. Molecular mimicry and the generation of host defense protein diversity. Cell 72:823-26

117. Hughes AL. 1997. Rapid evolution of immunoglobulin superfamily $\mathrm{C} 2$ domains expressed in immune system cells. Mol. Biol. Evol. 14:1-5

118. Smith LC, Davidson EH. 1992. The echinoid immune system and the phylogenetic occurrence of immune mechanisms in deuterostomes. Immunol. Today 13:35662

119. Rast JP, Litman GW. 1994. T cell receptor gene homologs are present in the most primitive jawed vertebrates. Proc. Natl. Acad. Sci. USA 91:9248-52

120. Hawke NA, Rast JP, Litman GW. 1996. Extensive diversity of transcribed TCR- $\beta$ in a phylogenetically primitive vertebrate. J. Immunol. 156:2458-64

121. Rast JP, Anderson MK, Strong SJ, Luer C, Litman RT, Litman GW. 1997. $\alpha, \beta, \gamma$, and $\delta \mathrm{T}$ cell antigen receptor genes arose early in vertebrate phylogeny. Immunity 6:1-11

122. Rast JP, Haire RN, Litman RT, Pross S, Litman GW. 1995. Identification and characterization of T-cell antigen receptor related genes in phylogenetically diverse vertebrate species. Immunogenetics 42:204-12

123. Luer CA. 1989. Elasmobranchs (sharks, skates, and rays) as animal models for biomedical research. In Nonmammalian Animal Models for Biomedical Research, ed. AD Woodhead, pp. 121-47. Boca Raton, FL: CRC

124. Campbell KS, Backstrom BT, Tiefenthaler G, Palmer E. 1994. CART: a conserved antigen receptor transmembrane motif. Semin. Immunol. 6:393-410

125. Partula S, Fellah JS, de Guerra A, Charlemagne J. 1994. Caractérisation d'ADNc de la chaine $\beta$ de récepteur des lymphocytes $\mathrm{T}$ chez la truite arc-en-ciel. $C$. $R$. Acad. Sci. Ser. III 317:765-70

126. Partula S, de Guerra A, Fellah JS, Charlemagne J. 1995. Structure and diversity of the $\mathrm{T}$ cell antigen receptor $\beta$-chain in a teleost fish. J. Immunol. 155:699-706

127. de Guerra A, Charlemagne J. 1997. Genomic organization of the TCR $\beta$-chain diversity $(\mathrm{D} \beta)$ and joining $(\mathrm{J} \beta)$ segments in the rainbow trout: presence of many repeated sequences. Mol. Immunol. 34:653-62

128. Hordvik I, Jacob ALJ, Charlemagne J, Endresen C. 1996. Cloning of T-cell antigen receptor $\beta$ chain cDNAs from Atlantic salmon (Salmo salar). Immunogenetics 45:9-14

129. Partula S, de Guerra A, Fellah JS, Charlemagne J. 1996. Structure and diversity of the TCR $\alpha$-chain in a teleost fish. J. Immunol. 157:207-12

130. Wilson MR, Zhou H, Bengten E, Clem LW, Stuge TB, Warr GW, Miller NW. 1998. T-cell receptors in channel catfish: structure and expression of TCR $\alpha$ and $\beta$ genes. Mol. Immunol. In press 
131. Chrétien I, Marcuz A, Fellah J, Charlemagne J, Du Pasquier L. 1997. The T cell receptor $\beta$ genes of Xenopus. Eur. J. Immunol. 27:763-71

132. Fellah JS, Kerfourn F, Guillet F, Charlemagne J. 1993. Conserved structure of amphibian T-cell antigen receptor $\beta$ chain. Proc. Natl. Acad. Sci. USA 90: 6811-14

133. Fellah JS, Kerfourn F, Charlemagne J. 1994. Evolution of T cell receptor genes: extensive diversity of $\mathrm{V} \beta$ families in the Mexican axolotl. J. Immunol. 153:453945

134. Fellah JS, Kerfourn F, Dumay AM, Aubet G, Charlemagne J. 1997. Structure and diversity of the T-cell receptor $\alpha$ chain in the Mexican axolotl. Immunogenetics 45:235-41

135. Lahti JM, Chen CL, Tjoelker LW, Pickel JM, Schat KA, Calnek BW, Thompson CB, Cooper MD. 1991. Two distinct $\alpha \beta$ T-cell lineages can be distinguished by the differential usage of T-cell receptor $\mathrm{V} \beta$ gene segments. Proc. Natl. Acad. Sci. USA 88:10956-60

136. Chen CH, Six A, Kubota T, Tsuji S, Kong F-K, Göbel TWF, Cooper MD. 1996. T cell receptors and $\mathrm{T}$ cell development. Curr. Top. Microbiol. Immunol. 212:3653

137. McCormack WT, Tjoelker LW, Stella G, Postema CE, Thompson CG. 1991. Chicken T-cell receptor $\beta$-chain diversity: an evolutionarily conserved $\mathrm{D}_{\beta^{-}}$ encoded glycine turn within the hypervariable CDR3 domain. Proc. Natl. Acad. Sci. USA 88:7699-703

138. Gobel TWF, Chen C-LH, Lahti J, Kubota T, Kuo C-L, Aebersold R, Hood L, Cooper MD. 1994. Identification of T cell receptor $\alpha$-chain genes in the chicken. Proc. Natl. Acad. Sci. USA 91:1094-98

139. Six A, Rast JP, McCormack WT, Dunon D, Courtois D, Li Y, Chen CH, Cooper MD. 1996. Characterization of avian Tcell receptor $\gamma$ genes. Proc. Natl. Acad. Sci. USA 93:15329-34

140. Hall BM, Roser BJ, Dorsch SE. 1977. Magnitude of memory to the major histocompatibility complex. Nature 268:53234

141. Perey DYE, Finstad J, Pollara B, Good RA. 1968. Evolution of the immune response. VI. First and second set skin homograft rejections in primitive fishes. Lab. Invest. 19:91-97

142. Borysenko M, Hildemann WH. 1970. Reactions to skin allografts in the horn shark, Heterodontus francisci. Transplantation 10:545-51
143. Hildemann WH. 1970. Transplantation immunity in fishes: Agnatha, Chondrichthyes and Osteichthyes. Transpl. Proc. 2:253

144. Estepa A, Thiry M, Coll JM. 1994. Recombinant protein fragments from haemorrhagic septicaemia rhabdovirus stimulate trout leukocyte anamnestic responses in vitro. J. Gen. Virol. 75:1329-38

145. Haire RN, Strong SJ, Litman GW. 1997. Identification and characterization of a homologue of Bruton's tyrosine kinase, a Tec kinase involved in B cell development, in a modern representative of a phylogenetically ancient vertebrate species. Immunogenetics 46:349-51

146. Okamura M, Matthews RJ, Robb B, Litman GW, Bork P, Thomas ML. 1996. Comparison of CD45 extracellular domain sequences from divergent vertebrate species suggests the conservation of three fibronectin type III domains. J. Immunol. 157:1569-75

147. Luer CA, Walsh CJ, Bodine AB, Wyffels JT, Scott TR. 1995. The elasmobranch thymus: anatomical, histological, and preliminary functional characterization. J. Exp. Zool. 273:342-54

148. Forey P, Janvier P. 1993. Agnathans and the origin of jawed vertebrates. Nature 361:129-34

149. Stock DW, Whitt GS. 1992. Evidence from $18 \mathrm{~S}$ ribosomal RNA sequences that lampreys and hagfishes form a natural group. Science 257:787-89

150. Zapata AG, Cooper EL, eds. 1990. The Immune System: Comparative Histophysiology. Chichester, UK: Wiley. $335 \mathrm{pp}$.

151. Georgopoulos K, Bigby M, Wang JH, Molnar A, Wu P, Winandy S, Sharpe A. 1994. The Ikaros gene is required for the development of all lymphoid lineages. Cell 79:143-56

152. Georgopoulos K, Winandy S, Avitahl N. 1997. The role of the Ikaros gene in lymphocyte development and homeostasis. Annu. Rev. Immunol. 15:155-76

153. Liippo J, Lassila O. 1997. Avian Ikaros gene is expressed early in embryogenesis. Eur. J. Immunol. 27:1853-57

154. Hansen JD, Strassburger P, Du Pasquier L. 1997. Conservation of a master hematopoietic switch gene during vertebrate evolution: isolation and characterization of Ikaros from teleost and amphibian species. Eur. J. Immunol. 27:3049-58

155. Liu Y-J, Banchereau J. 1997. Regulation of B cell commitment to plasma cells or to memory B cells. Semin. Immunol. 9:23540

156. Ramsden DA, Baetz K, Wu GE. 1994. 
Conservation of sequence in recombination signal sequence spacers. Nucleic Acids Res. 22:1785-96

157. Lewis SM, Wu GE. 1997. The origins of V(D)J recombination. Cell 88:159-62

158. Greehalgh P, Steiner LA. 1995. Recombination activating gene 1 (Rag1) in zebrafish and shark. Immunogenetics 41:54-55

159. Bernstein RM, Schluter SF, Bernstein H, Marchalonis JJ. 1996. Primordial emergence of the recombination activating gene 1 (RAG1): sequence of the complete shark gene indicates homology to microbial integrases. Proc. Natl. Acad. Sci. USA 93:9454-59

160. Greenhalgh P, Olesen CEM, Steiner LA. 1993. Characterization and expression of recombination activating genes (RAG-1 and RAG-2) in Xenopus laevis. J. Immunol. 151:3100-10

161. Hansen JD, Kaattari SL. 1996. The recombination activating gene 2 (RAG2) of the rainbow trout Oncorhynchus mykiss. Immunogenetics 44:203-11

162. Willett CE, Cherry JJ, Steiner LA. 1997. Characterization and expression of the recombination activating genes (rag1 and rag2) of zebrafish. Immunogenetics 45:394-404

163. Hansen JD, Kaattari SL. 1995. The recombination activating gene 1 (RAGl) of rainbow trout (Oncorhynchus mykiss): cloning, expression and phylogenetic analysis. Immunogenetics 42:188-95

164. Lee A, Hsu E. 1994. Isolation and characterization of the Xenopus terminal de- oxynucleotidyl transferase. J. Immunol. 152:4500-7

165. Hansen JD. 1997. Characterization of rainbow trout terminal deoxynucleotidyl transferase structure and expression. $T d T$ and $R A G 1$ co-expression define the trout primary lymphoid tissues. Immunogenetics 46:367-75

166. Lanier LL. 1998. NK cell receptors. Annu. Rev. Immunol. 16:359-93

167. Chrétien I, Robert J, Marcuz A, GarciaSanz JA, Courtet M, Du Pasquier L. 1996. CTX, a novel molecule specifically expressed on the surface of cortical thymocytes in Xenopus. Eur. J. Immunol. 26:780-91

168. Katevuo K, Imhof BA, Boyd R, Chidgey A, Bean A, Dunon D, Göbel TWF, Vainio O. 1998. ChT1, an IgSF molecule required for T cell differentiation. Submitted for publication

169. Chrétien I, Marcuz A, Courtet M, Katevuo K, Vainio O, Heath JK, White SJ, Du Pasquier L. 1998. CTX, a Xenopus thymocyte receptor, defines a molecular family conserved throughout vertebrates. Eur. J. Immunol. 28:1-11

170. Du Pasquier L, Chrétien I. 1996. CTX, a new lymphocyte receptor in Xenopus, and the early evolution of Ig domains. Res. Immunol. 147:218-26

171. Agrawal A, Eastman QM, Schatz DG. 1998. Transposition mediated by the $\mathrm{V}(\mathrm{D}) \mathrm{J}$ recombination proteins RAG1 and RAG2: implications for the origins of the antigen-specific immune system. Nature 394:744-51 


\section{CONTENTS}

Discovering the Origins of Immunological Competence, Jacques F. A. P. Miller

Multifaceted Regulation of IL-15 Expression and Its Role in NK Cell

Differentiation \& Host Response to Intracellular Pathogens, T. A.

Waldmann, Y. Tagaya

Immunodominance in Major Histocompatibility Complex Class I-

Restricted T Lymphocyte Responses, Jonathan W. Yewdell, Jack R.

Bennink

Integration of TCR-Dependent Signaling Pathways by Adapter Proteins, James L. Clements, Nancy J. Boerth, Jong Ran Lee, Gary A. Koretzky

Evolution of Antigen Binding Receptors, Gary W. Litman, Michele K.

Anderson, Jonathan P. Rast

Transcriptional Regulation of T Lymphocyte Development and Function,

Chay T. Kuo, Jeffrey M. Leiden

Natural Killer Cells in Antiviral Defense: Function and Regulation by

Innate Cytokines, Christine A. Biron, Khuong B. Nguyen, Gary C. Pien,

Leslie P. Cousens, Thais P. Salazar-Mather

Mature T Lymphocyte Apoptosis--Immune Regulation in a Dynamic and Unpredictable Antigenic Environment, Michael Lenardo, Francis Ka-

Ming Chan, Felicita Hornung, Hugh McFarland, Richard Siegel, Jin

Wang, Lixin Zheng

Immunologic Basis of Antigen-Induced Airway Hyperresponsivenes,

Marsha Wills-Karp

Regulation of T Cell Fate by Notch, Ellen Robey

The CD1 System: Antigen Presenting Molecules for T Cell Recognition of Lipids and Glycolipids, Steven A. Porcelli, Robert L. Modlin

Tumor Necrosis Factor Receptor and Fas Signaling Mechanisms, $D$.

Wallach, E. E. Varfolomeev, N. L. Malinin, Yuri V. Goltsev, A. V.

Kovalenko, M. P. Boldin

Structural Basis of T Cell Recognition, K. Christopher Garcia, Luc

Teyton, Ian A. Wilson

Development and Maturation of Secondary Lymphoid Tissues, Yang-Xin

Fu, David D. Chaplin

The Structural Basis of T Cell Activation by Superantigens, Hongmin Li, Andrea Llera, Emilio L. Malchiodi, Roy A. Mariuzza

The Dynamics of T Cell Receptor Signaling: Complex Orchestration and the Key Roles of Tempo and Cooperation, Ronald N. Germain, Irena Stefanová

The Regulation of CD4 and CD8 Coreceptor Gene Expression During T

Cell Development, Wilfried Ellmeier, Shinichiro Sawada, Dan R. Littman

Genetic Analysis of B Cell Antigen Receptor Signaling, Tomohiro Kurosaki

Mechanisms of Phagocytosis in Macrophages, Alan Aderem, David M.

Underhill

Population Biology of HIV-1 Infection: Viral and CD4+ T Cell

Demographics and Dynamics in Lymphatic Tissues, A. T. Haase 
Chemokine Receptors as HIV-1 Coreceptors: Roles in Viral Entry,

Tropism, and Disease, Edward A. Berger, Philip M. Murphy, Joshua M.

Farber

The IL-4 Receptor: Signaling Mechanisms and Biologic Functions, Keats

Nelms, Achsah D. Keegan, José Zamorano, John J. Ryan, William E.

701

Paul

Degradation of Cell Proteins and the Generation of MHC Class I-

Presented Peptides, Kenneth L. Rock, Alfred L. Goldberg

739

The Central Effectors of Cell Death in the Immune System, Jeffrey $C$.

Rathmell, Craig B. Thompson

781

Selection of the T Cell Repertoir, Eric Sebzda, Sanjeev Mariathasan,

Toshiaki Ohteki, Russell Jones, Martin F. Bachmann, Pamela S. Ohashi

829

Regulation of Immune Responses Through Inhibitory Receptors, Eric O.

Long

875

The Wiskott-Aldrich Syndrome Protein (WASP): Roles in Signaling and

Cytoskeletal Organization, Scott B. Snapper, Fred S. Rosen

905

The High Affinity IgE Receptor (Fc Epsilon RI): From Physiology to

Pathology, Jean-Pierre Kinet

931

THE CRYSTAL STRUCTURE OF THE HUMAN HIGH-AFFINITY

IgE RECEPTOR (Fc epsilon RI alpha), Scott C. Garman, Jean-Pierre

Kinet, Theodore S. Jardetzky 